\title{
Important advances in Alzheimer's disease from the use of induced pluripotent stem cells
}

Fernanda Majolo* ${ }^{*}$, Daniel Rodrigo Marinowic, Denise Cantarelli Machado and Jaderson Costa Da Costa

\begin{abstract}
Among the various types of dementia, Alzheimer's disease (AD) is the most prevalent and is clinically defined as the appearance of progressive deficits in cognition and memory. Considering that AD is a central nervous system disease, getting tissue from the patient to study the disease before death is challenging. The discovery of the technique called induced pluripotent stem cells (iPSCs) allows to reprogram the patient's somatic cells to a pluripotent state by the forced expression of a defined set of transcription factors. Many studies have shown promising results and made important conclusions beyond AD using iPSCs approach. Due to the accumulating knowledge related to this topic and the important advances obtained until now, we review, using PubMed, and present an update of all publications related to AD from the use of iPSCs. The first iPSCs generated for AD were carried out in 2011 by Yahata et al. (PLoS One 6:e25788, 2011) and Yaqi et al. (Hum Mol Genet 20:4530-9, 2011). Like other authors, both authors used iPSCs as a pre-clinical tool for screening therapeutic compounds. This approach is also essential to model AD, testing early toxicity and efficacy, and developing a platform for drug development. Considering that the iPSCs technique is relatively recent, we can consider that the AD field received valuable contributions from iPSCs models, contributing to our understanding and the treatment of this devastating disorder.
\end{abstract}

Keywords: Alzheimer's disease, Induced pluripotent stem cells, PubMed

\section{Introduction}

Along with the aging population and as the main consequence of this, there is an increase in neurodegenerative diseases, including Alzheimer's disease (AD) [137]. Dementia associated with several fatal clinical disorders is a considerable social, economic, and medical challenge [30]. By reaching approximately 50 million people, it has become a public health problem, with the global cost of US $\$ 818$ billion for the treatment $[3,30]$. Among the various types of dementia, $\mathrm{AD}$ is the most prevalent one and has been clinically defined as the appearance of progressive deficits in cognition and memory [10, 34].

\footnotetext{
* Correspondence: fernandamajolo@hotmail.com

Brain Institute of Rio Grande do Sul (Bralns), Postgraduate Program in

Medicine and Health Sciences (PUCRS), Pontifical Catholic University of Rio

Grande do Sul, Porto Alegre, RS 90610000, Brazil
}

There are two types of $\mathrm{AD}$ : Familial $\mathrm{AD}(\mathrm{FAD})$ and Sporadic AD (SAD). Both share clinical and pathological similarities, exhibiting progressive cognitive dementia, senile plaques consisting of amyloid $\beta(A \beta)$ peptide and neurofibrillary tangles (NFTs) consisting of phosphorylated tau protein [62, 137]. Axonal transport defects, synapse loss and selective neuronal death are others cellular phenotypes shared by FAD and SAD [38, 43, 137].

FAD: early-onset, accounts for $5 \%$ of cases and is caused by highly penetrant and rare autosomal mutations of the PS1, PS2 and, less frequently, amyloid precursor protein (APP) genes. APP protein is fundamental for central nervous system (CNS) function acting in the formation of synapses, neurogenesis, axonal transport, signaling and plasticity [17, 41, 43, 58, 137].

SAD: late-onset, has established risk factors beyond age including cardiovascular disease, low education,

(c) The Author(s). 2019 Open Access This article is distributed under the terms of the Creative Commons Attribution 4.0 International License (http://creativecommons.org/licenses/by/4.0/), which permits unrestricted use, distribution, and reproduction in any medium, provided you give appropriate credit to the original author(s) and the source, provide a link to the Creative Commons license, and indicate if changes were made. The Creative Commons Public Domain Dedication waiver (http://creativecommons.org/publicdomain/zero/1.0/) applies to the data made available in this article, unless otherwise stated. 
depression, and the apolipoprotein-E4 (ApoE4) gene [30]. There are no clear dominant or recessive SAD mutations; however, many genetic variants have been identified and there is clearly a strong heritable component to the disorder [6, 137]. Thus, SAD has multifactorial origins, driven in part by a complex genetic profile and in part by environmental factors and the interaction of the two [30].

$\mathrm{AD}$ reaches the central nervous system (CNS); it is difficult to obtain samples of the patient's nervous tissue before his death to study the disease [137]. It is possible, using the relatively recent technique called induced pluripotent stem cells (iPSCs), to study the genesis of diseases and identify new molecular targets that recapitulate the genetic background of the individual from disease models in the laboratory.

\section{Induced pluripotent stem cells}

The models of diseases, truly representing real human diseases and their physiological peculiarities, that can be recreated in the laboratory, are needed to increase the success rate of new drug discoveries and developments [141]. In addition, the studies conducted in animal models do not efficiently show the translation of the therapeutic discovery for human use, although they are valuable in elucidating diseases and directing markers and genes associated with certain pathologies [27]. Specifically, regarding AD, vertebrate and nonvertebrate models can cause abnormal phenotypes mainly because of considerable overexpression of proteins. Notably, the mutations introduced into the endogenous mouse genes, unfortunately, do not recapitulate all the pathologies of the human $\mathrm{AD}[29$, 137]. In addition, the studies already using postmortem tissue show major structural changes in the brain, both at the cellular and molecular levels.

After the discovery of the iPSCs in 2006 by Yamanaka and colleagues, it became possible to reprogram the patient's somatic cells back to a pluripotent state, forcing the expression of a defined set of transcription factors. For this reprogramming, four transcription factors need to be introduced into fibroblasts through retroviruses. Consequently, the cells acquire a pluripotent stage with characteristics extremely similar to the embryonic stem cells [83]. The first transfection was performed on mouse fibroblasts [121], followed by transfection into human fibroblasts [120].

Considering the difficulty of obtaining CNS tissue from the patients with AD, the discovery of iPSCs shows a great potential and advantage to enable the modeling of in vitro diseases. For example, disease-specific cells from patients with $\mathrm{AD}$ can be produced with disorders without a clear pattern of inheritance and sporadic cases can be used in drug discovery programs [83].

Parkinson's disease [78, 87, 101, 115], amyotrophic lateral sclerosis [25, 74], smooth muscle atrophy [31], and family dysautonomia [61] were the diseases initially studied using the iPSCs approach to model neurological diseases. These are monogenic disorders or versions of complex diseases caused by known mutations [72, 137].

\section{Important advances in Alzheimer's disease using iPSCs}

Many studies have shown promising results and important conclusions, beyond AD, using iPSCs allowing a better understanding of cellular and molecular targets. Here we review and present an update of all publications related to $\mathrm{AD}$ from the use of iPSCs (Table 1). Electronic databases, including PubMed, were searched for articles related to the use of iPSCs in AD research. Only full-text English-language articles were included. If the abstract met the inclusion criteria, the full-text article was obtained and reviewed. The flow diagram below shows which terms were searched and how many articles were excluded at each step and the reasons (Fig. 1).

One of the first studies involving iPSCs generated for AD were carried out in 2011 by Yahata et al. [133] and Yaqi et al. [131]. Yahata et al., [133] successfully generated forebrain neurons from human iPSCs cells, and showed that $A \beta$ production in neuronal cells was detectable and inhibited by some typical secretase inhibitors and modulators. According to the authors, hiPSCs cell-derived neuronal cells express functional $\beta$ - and $\gamma$-secretases involved in $A \beta$ production. However, anti-A $\beta$ drug screening using these hiPS cell-derived neuronal cells requires sufficient neuronal differentiation. Also, Yaqi et al. [131] generated iPSCs from fibroblasts of FAD patients with mutations in PS1 (A246E) and PS2 (N141I) and characterized the differentiation of these cells into neurons. The authors demonstrated that patient-derived differentiated neurons have increased Ab42 secretion, recapitulating the pathological mechanism of FAD with PS1 and PS2 mutations.

Taken together, along with others, these two studies represent, thus, critical first steps in assessing the potential of AD iPSCs to model AD. iPSCs are a pre-clinical tool for screening therapeutic compounds.

In addition, this approach is central to toxicity and efficacy testing, in the new drug development landscape and the precise engineering of the genome and transcriptional and proteomic analyses. Thus, human cells can demonstrate pathogenic mutations in vitro, which can then be functionally validated and downstream targets can be confirmed. In the future, these models can give rise to a new preclinical model for drug discovery 
Table 1 Update of all publications until now involving iPSCs approach in Alzheimer's disease

\begin{tabular}{|c|c|c|c|c|}
\hline TARGET & & MAJOR FINDINGS & YEAR & REFERENCE \\
\hline FAMILIAL AD & $\begin{array}{l}\text { A } \beta \text {; Astrocyte; } \\
\text { Lipoprotein receptor }\end{array}$ & $\begin{array}{l}\text { APP-KO astrocytes have reduced } \\
\text { cholesterol and elevated levels of } \\
\text { sterol regulatory element-binding } \\
\text { protein (SREBP) target gene } \\
\text { transcripts and proteins, which } \\
\text { were both downstream consequences } \\
\text { of reduced lipoprotein endocytosis. }\end{array}$ & 2018 & Fong et al [36] \\
\hline
\end{tabular}

Sendai-virus

Aß; Tau; Amyloid; Disease modeling; Selective vulnerability

$A \beta ;$ sAPPa; Microengraving

A $\beta$; Proteolytic Enzyme; BACE1

Disease model

5XFAD mice; Oligodendrocyte; Protein-iPSC; Proteomic analysis
Dermal fibroblasts of the patient were obtained and a line of iPSCs was successfully generated using the Sendai virus (SeV) delivery system.

Both the generation of $A \beta$ and the responsiveness of TAU

to $A B$ are affected by neurona cell type, with rostral neurons being more sensitive than

caudal neurons. Cell-autonomous factors may in part dictate the pattern of selective regional vulnerability

in human neurons in $A D$.

The authors have uncovered the dynamic range of secretion profiles of analytes from single iPSCs-derived neuronal and glial cells and have molecularly characterized subpopulations

of these cells through immunostaining and gene expression analyses.

Demonstrate that A673T, a protective allele of APP, reproducibly reduces amyloidogenic processing of APP and also mildly decreases $A \beta$ aggregation. These effects could together have an additive or even synergistic impact on the risk of developing $A D$.

Over differentiation time to mature neuronal fates, APP expression and levels of $A B$ increase dramatically. In both immature and mature neuronal fates, the APPV717I mutation affects both $\beta$ - and $\gamma$-secretase cleavage of APP. $\beta$-secretase cleavage of APP is elevated leading to generation of increased levels of both APPs $\beta$ and $A \beta$.

This mutation alters the initial cleavage site of $\gamma$-secretase, resulting in an increased generation of both $A \beta 42$ and $A \beta 38$. An increase in levels of total and phosphorylated

Tau is observed in neurons with the APPV717I mutation. Treatment with $A \beta$-specific antibodies early in culture reverses the phenotype of increased total Tau levels, implicating altered $A B$ production in FAD neurons in this phenotype.

Protein-iPSCs differentiated into glial cells and decreased plaque depositions in the 5XFAD transgenic AD mouse model. Transplanted protein-iPSCs mitigated the cognitive dysfunction 
Table 1 Update of all publications until now involving iPSCs approach in Alzheimer's disease (Continued)

Endocytosis; Transcytosis

Mono- and bi-allelic sequence changes

Therapeutic potential; Macrophage-like cells

ASM; Lysosomal depletion

Apoptosis; NPCs

282F mutation in PS

MAJOR FINDINGS

observed in these mice. Proteomic

analysis revealed that

oligodendrocyte-related

genes were upregulated

in brains injected with

protein-iPSCs, providing

new insights into the

potential function of protein-iPSCs.

Accumulation of $\beta$-CTFs

of APP, but not $A B$, slow

vesicle formation from an

endocytic recycling

compartment marked by

the transcytotic GTPase Rab11.

The authors confirm previous

results that endocytosis is

affected in $A D$ and extend

these to uncover a

neuron-specific defect.

Decreased lipoprotein

endocytosis and transcytosis

to the axon suggest that

a neuron-specific impairment

in endocytic axonal delivery

of lipoproteins and other

key materials might

compromise synaptic

maintenance in FAD.

The authors generated

human iPSCs with

heterozygous and

homozygous dominant

early onset $A D$ causing

mutations in APP(Swe)

and PS1(M146V) and

derived cortical neurons,

which displayed

genotype-dependent

disease-associated phenotypes.

In vitro, expression of

NEP2 but not anti-A $\beta$ scFv

enhanced the effect to

reduce the level of soluble

$A \beta$ oligomer in the culture

medium and to alleviate

the neurotoxicity of $A B$.

The authors observed

significant reduction in

the level of $A \beta$ in the brain

interstitial fluid following

administration of iPSCs-ML/NEP2.

Reveal a novel mechanism

of ASM pathogenesis in AD

that leads to defective autophagy

due to impaired lysosomal

biogenesis and suggests that

partial ASM inhibition is a

potential new therapeutic

intervention for the disease.

Premature neuronal differentiation with decreased proliferation and increased apoptosis occurred in

AD-iPSCs-derived-NPCs once neuronal differentiation

was initiated, together

with higher levels of

Aß42 and phosphorylated tau.

The authors transfected

skin fibroblasts with

episomal iPSCs reprogramming

vectors targeting human

OCT4, SOX2, L-MYC, KLF4, 
Table 1 Update of all publications until now involving iPSCs approach in Alzheimer's disease (Continued)

Disease model; M146I mutation

Disease model; A79V mutation

L150P mutation

3 different mutations; GSM

Non integrating vectors

NPCs

\section{MAJOR FINDINGS \\ NANOG, LIN28, and short hairpin}

RNA against TP53.

This gene-corrected line,

L150P-GC-hiPSCs, serves as

an isogenic control to the

mutant line for future

investigation of mechanisms

and cellular phenotypes

altered by this

specific PS1 mutation.

M1461-iPSCs were free of genomically integrated reprogramming genes, had

the specific mutation but

no additional genomic

aberrancies, expressed the

expected pluripotency markers

and displayed in vitro

differentiation potential to

the three germ layers.

The reported M146l-iPSCs

line may be a useful

resource for in vitro

modeling of $F A D$.

A79V-iPSCs were free of

genomically integrated

reprogramming genes, had

the specific mutation but

no additional genomic

aberrancies, expressed

the expected pluripotency

markers and displayed

in vitro differentiation

potential to the three germ layers.

The iPSCs were established

by co-electroporation with

episomal plasmids containing

hOCT4, hSOX2, hL-MYC,

hKLF4, hNANOG, hLIN28,

and short hairpin RNA

against TP53. The iPSCs

contained the specific

heterozygous mutation

c.449C > T, had normal

karyotype, expressed the

expected pluripotency

genes and displayed in

vitro differentiation

potential to the three germ layers.

Biomarker signatures

obtained with such models

are misleading and that

human neurons derived

from hiPSCs provide a

unique signature that

will more accurately

reflect drug response

in human patients and

in cerebrospinal fluid

biomarker changes

observed during GSM treatment.

Neurons from mutant hiPSC

lines express PS1-A246E

mutations themselves

and show AD-like biochemical

features, that is, amyloidogenic

processing of APP indicated

by an increase in $A \beta 42 / A \beta 40$ ratio.

PS1 mutant fibroblasts and

NPCs produced greater

ratios of $A B 42$ to $A \beta 40$

relative to their control

counterparts, with the

\section{YEAR}

REFERENCE

2016

Poon et al [90]

2016

Li et al [64]

2016 Li et al [65] 
Table 1 Update of all publications until now involving iPSCs approach in Alzheimer's disease (Continued)

\begin{tabular}{|c|c|c|c|c|}
\hline TARGET & & MAJOR FINDINGS & YEAR & REFERENCE \\
\hline & & $\begin{array}{l}\text { elevated ratio even more } \\
\text { apparent in PS1 NPCs } \\
\text { than in fibroblasts. }\end{array}$ & & \\
\hline & Allelic series mutations; & $\begin{array}{l}\text { FAD PS1 mutations do not } \\
\text { act as simple loss of PS1 } \\
\text { function but instead } \\
\text { dominantly gain an } \\
\text { activity toxic to some, } \\
\text { but not all, PS1 functions. }\end{array}$ & 2013 & Woodruff et al [129] \\
\hline & Proteolytic APP processing & $\begin{array}{l}\text { The human NSC-derived } \\
\text { neurons express the } \\
\text { neuron-specific APP(695) } \\
\text { splice variant, BACE1, and } \\
\text { all members of the } \\
\text { Y-secretase complex. } \\
\text { They also exhibit a } \\
\text { differentiation-dependent } \\
\text { increase in Aß secretion } \\
\text { and respond to the } \\
\text { pharmacotherapeutic } \\
\text { modulation by anti-amyloidogenic } \\
\text { compounds, such as } \gamma \text {-secretase } \\
\text { inhibitors and nonsteroidal } \\
\text { anti-inflammatory drugs. }\end{array}$ & 2012 & Koch et al [54] \\
\hline & Aß42 secretion & $\begin{array}{l}\text { FAD-iPSCs-derived differentiated } \\
\text { neurons have increased toxic } \\
\text { A } 42 \text { secretion, recapitulating } \\
\text { the molecular pathogenesis } \\
\text { of mutant presenilins. Secretion } \\
\text { of A } 42 \text { from these neurons } \\
\text { sharply responds to } y \text { secretase } \\
\text { inhibitors and modulators, } \\
\text { indicating the potential for } \\
\text { identification and validation } \\
\text { of candidate drugs. }\end{array}$ & 2012 & Yagi et al [130] \\
\hline & $\begin{array}{l}\text { Amyloid; Bodily secretions; } \\
\text { Cognitive impairment }\end{array}$ & $\begin{array}{l}\text { FAD-iPSCs-derived differentiated } \\
\text { neurons have increased } \\
\text { A } 42 \text { secretion, recapitulating } \\
\text { the molecular pathogenesis } \\
\text { of mutant presenilins. }\end{array}$ & 2011 & Yagi et al [131] \\
\hline & BFCN; BFCNs; Electrophysiology & $\begin{array}{l}\text { Cell lines harboring the } \\
\text { PS2 N141I mutation } \\
\text { displayed an increase } \\
\text { in the A } 42 / 40 \text { in } \\
\text { iPSCs-derived BFCNs. } \\
\text { Neurons derived from } \\
\text { PS2 N141I lines generated } \\
\text { fewer maximum number } \\
\text { of spikes in response to } \\
\text { a square depolarizing } \\
\text { current injection. }\end{array}$ & 2017 & Ortiz-Virumbrales et al [84] \\
\hline & Fibroblast library; DIAN & $\begin{array}{l}\text { The authors reprogrammed } \\
\text { a subset of the DIAN } \\
\text { fibroblast lines into iPSCs lines. }\end{array}$ & 2018 & Karch et al [52] \\
\hline & $\begin{array}{l}\text { A } \beta \text { hypothesis; Anti-cancer } \\
\text { drugs; Clinical trials; Semagacestat; } \\
\text { } \text {-by products; } \gamma \text {-secretase inhibitors }\end{array}$ & $\begin{array}{l}\text { Some semagacestat effects } \\
\text { are clearly different from } \\
\text { a phenotype caused by } \\
\text { a loss of function of presenilins, } \\
\text { core proteins in the } \gamma \text {-secretase } \\
\text { complex. Semagacestat increases } \\
\text { intracellular byproduct peptides, } \\
\text { produced along with A } \beta \text { through } \\
\text { serial } \gamma \text {-cleavage of } \beta A P P \text {, } \\
\text { as well as intracellular long } \\
\text { A } \beta \text { species, in cell-based and } \\
\text { in vivo studies of AD model mice. }\end{array}$ & 2017 & Tagami et al [109] \\
\hline & Cerebral organoids; Cdk5; Isogenic; Tauopathy & $\begin{array}{l}\text { Significant reduction of } \\
\text { phosphorylated tau and its } \\
\text { seeding activity in the brain } \\
\text { of double transgenic mice } \\
\text { compared with the P301S } \\
\text { mice. Synaptic loss and }\end{array}$ & 2017 & Seo et al [102] \\
\hline
\end{tabular}


Table 1 Update of all publications until now involving iPSCs approach in Alzheimer's disease (Continued)

\begin{tabular}{|c|c|c|c|c|}
\hline TARGET & & MAJOR FINDINGS & YEAR & REFERENCE \\
\hline & & $\begin{array}{l}\text { impaired LTP at hippocampal } \\
\text { CA3 region of P301S mice } \\
\text { were attenuated by blocking p25 } \\
\text { generation. Blockade of p25 } \\
\text { generation reduced levels of } \\
\text { phosphorylated tau and } \\
\text { increased expression } \\
\text { of synaptophysin. }\end{array}$ & & \\
\hline & $\begin{array}{l}\text { 3D organoids; } A \beta ; \text { Tau; } \\
\text { AD-GWAS; iMGLs }\end{array}$ & $\begin{array}{l}\text { iMGLs develop in vitro similarly } \\
\text { to microglia in vivo, and } \\
\text { whole-transcriptome analysis } \\
\text { demonstrates that they } \\
\text { are highly similar to } \\
\text { cultured adult and } \\
\text { fetal human microglia. }\end{array}$ & 2017 & Abud et al [1] \\
\hline & $\begin{array}{l}\text { A } \beta 42 / A \beta 40 \text { ratio; Alzheimerogen; } \\
\text { A } \beta ; A \beta \text { Herbicides; HCE; Triazines }\end{array}$ & $\begin{array}{l}\text { Neurons derived from iPSCs } \\
\text { obtained from a FAD patient } \\
\text { (AßPP K724 N) produced more } \\
\text { A } 42 \text { versus A } 440 \text { than neurons } \\
\text { derived from healthy controls } \\
\text { iPSCs (A } 3 P P \text { WT). Triazines } \\
\text { enhanced A } 42 \text { production in } \\
\text { both control and AD iPSCs-derived } \\
\text { neurons. Triazines also shifted } \\
\text { the cleavage pattern of alcadeina, } \\
\text { another } \gamma \text {-secretase substrate, } \\
\text { suggesting a direct effect of } \\
\text { triazines on } \gamma \text {-secretase activity. }\end{array}$ & 2016 & Portelius et al [91] \\
\hline & BACE; Neuregulin; Amyloid & $\begin{array}{l}\text { Subcellular compartmentalization } \\
\text { allows BACE1 to cleave APP } \\
\text { in the endosomal compartment } \\
\text { and other non-amyloid substrates } \\
\text { in non-endosomal compartments. }\end{array}$ & 2016 & Ben et al [9] \\
\hline & Signaling events & $\begin{array}{l}\text { Over a timeframe that mirrors } \\
\text { human development, these } \\
\text { progenitors give rise to } \\
\text { functional lower and upper } \\
\text { layer neurons. }\end{array}$ & 2016 & Saurat et al [97] \\
\hline & $\begin{array}{l}\text { Fibroblasts; Postmortem; } \\
\text { Centenarian donors }\end{array}$ & $\begin{array}{l}\text { The expression of molecules } \\
\text { that play critical roles in late-onset } \\
\text { neurodegenerative diseases by } \\
\text { neurons differentiated from the } \\
\text { centenarian-iPSCs was compared } \\
\text { to that of neurons differentiated } \\
\text { from iPSCs derived from FAD } \\
\text { and familial Parkinson's } \\
\text { disease patients. }\end{array}$ & 2012 & Yagi et al [132] \\
\hline & $\begin{array}{l}\text { DS; Development of } \\
\text { AD pathologies }\end{array}$ & $\begin{array}{l}\text { Hyperphosphorylated tau protein, } \\
\text { a pathological hallmark of AD, } \\
\text { was found to be localized to } \\
\text { cell bodies and dendrites in } \\
\text { iPSCs-derived cortical neurons } \\
\text { from Down syndrome } \\
\text { patients, recapitulating } \\
\text { later stages of the AD } \\
\text { pathogenic process. }\end{array}$ & 2012 & Shi et al [104] \\
\hline SPORADIC AD & A $\beta ;$ Mitochondria & $\begin{array}{l}\text { Neuronal cultures from } \\
\text { some patients produced } \\
\text { more reactive oxygen species } \\
\text { and displayed higher levels } \\
\text { of DNA damage. Patient-derived } \\
\text { cells showed increased levels } \\
\text { of oxidative phosphorylation } \\
\text { chain complexes, whereas } \\
\text { mitochondrial fission and } \\
\text { fusion proteins were not affected. }\end{array}$ & 2018 & Birnbaum et al [13] \\
\hline & $\begin{array}{l}\text { PBMC; Homozygous APOE4 } \\
\text { AD: ASUi003-A; non-demented } \\
\text { control: ASUi004-A }\end{array}$ & $\begin{array}{l}\text { hiPSCs maintained their } \\
\text { original genotype, expressed } \\
\text { pluripotency markers, } \\
\text { exhibited a normal karyotype, } \\
\text { and retained the ability to } \\
\text { differentiate into cells }\end{array}$ & 2017 & Brookhouser et al [14] \\
\hline
\end{tabular}


Table 1 Update of all publications until now involving iPSCs approach in Alzheimer's disease (Continued)

\begin{tabular}{|c|c|c|c|c|}
\hline TARGET & & MAJOR FINDINGS & YEAR & REFERENCE \\
\hline & & $\begin{array}{l}\text { representative of the } \\
\text { three germ layers. }\end{array}$ & & \\
\hline & $\begin{array}{l}\text { PBMCs; Homozygous APOE4 risk allele } \\
\text { AD: ASUi001-A; non-demented } \\
\text { control: ASUi002-A }\end{array}$ & $\begin{array}{l}\text { hiPSCs maintained their } \\
\text { original genotype, expressed } \\
\text { pluripotency markers, exhibited } \\
\text { a normal karyotype, and } \\
\text { demonstrated the ability to } \\
\text { differentiate into cells } \\
\text { representative of the } \\
\text { three germ layers. }\end{array}$ & 2017 & Brookhouser et al [15] \\
\hline & Glucose MetS/T2DM; NMDA receptor & $\begin{array}{l}\text { Redox-mediated posttranslational } \\
\text { modification of brain } \\
\text { proteins link } A \beta \text { and } \\
\text { hyperglycaemia to } \\
\text { cognitive dysfunction } \\
\text { in MetS/T2DM and AD. }\end{array}$ & 2016 & Akhtar et al [2] \\
\hline & $\begin{array}{l}\text { Neurodegeneration; Pathology } \\
\text { propagation; Tau oligomer seeds }\end{array}$ & $\begin{array}{l}\text { Tau oligomers, but not } \\
\text { monomers, induce } \\
\text { accumulation of pathological, } \\
\text { hyperphosphorylated tau. } \\
\text { This effect was accompanied } \\
\text { with neurite degeneration, } \\
\text { loss of synapses, aberrant } \\
\text { calcium homeostasis, } \\
\text { imbalanced neurotransmitter } \\
\text { release, and ultimately } \\
\text { with neuronal death. }\end{array}$ & 2015 & Usenovic et al [124] \\
\hline & SORL1 gene & $\begin{array}{l}\text { The variation in SORL1 } \\
\text { expression induction by } \\
\text { BDNF is modulated by } \\
\text { common genetic variants } \\
\text { and can explain how genetic } \\
\text { variation in this one locus can } \\
\text { contribute to an individual's } \\
\text { risk of developing SAD. }\end{array}$ & 2015 & Young et al [136] \\
\hline & Dermal fibroblasts; 82 year old female & $\begin{array}{l}\text { The expression of p-tau } \\
\text { and GSK3B, a physiological } \\
\text { kinase of tau, in neuronal } \\
\text { cells derived from AD-iPSCs. } \\
\text { Treatment of neuronal } \\
\text { cells differentiated from } \\
\text { AD-iPSCs with an inhibitor } \\
\text { of } \gamma \text {-secretase resulted } \\
\text { in the down-regulation of p-tau. }\end{array}$ & 2015 & Hossini et al [44] \\
\hline & BFCNs; ApoE3/E4 genotypes (AD-E3/E4) & $\begin{array}{l}\text { BFCNs derived from } \\
\text { AD-E3/E4 patients showed } \\
\text { typical AD biochemical } \\
\text { features evidenced by } \\
\text { increased } A \beta 42 / A \beta 40 \text { ratios. } \\
\text { AD-E3/E4 neurons also } \\
\text { exhibited altered responses } \\
\text { to treatment with } \gamma \text {-secretase } \\
\text { inhibitors compared to } \\
\text { control BFCNs or neurons } \\
\text { derived from patients with FAD. }\end{array}$ & 2014 & Duan et al [28] \\
\hline & $\begin{array}{l}\text { Frozen non-cryoprotected } \\
\text { tissue; Autopsy cohort }\end{array}$ & $\begin{array}{l}\text { Disease-specific iPSCs can } \\
\text { be generated from readily } \\
\text { available, archival biobanked } \\
\text { tissue. This allows for } \\
\text { rapid expansion of generating } \\
\text { iPSCs with confirmed pathology } \\
\text { as well as allowing access } \\
\text { to rare patient variants } \\
\text { that have been banked. }\end{array}$ & 2014 & Sproul et al [117] \\
\hline FAMILIAL AD AND SPORADIC AD & $\begin{array}{l}\text { Aß; GSK3B; Hyper } \\
\text { phosphorylation; } \\
\text { TAU pathology }\end{array}$ & $\begin{array}{l}\text { Neurons from patients with } \\
\text { FAD and patients with SAD } \\
\text { showed increased phosphorylation } \\
\text { of TAU protein at all investigated } \\
\text { phosphorylation sites. Neurons } \\
\text { derived from patients with FAD } \\
\text { and patients with SAD exhibited } \\
\text { higher levels of extracellular }\end{array}$ & 2017 & Ochalek et al [80] \\
\hline
\end{tabular}


Table 1 Update of all publications until now involving iPSCs approach in Alzheimer's disease (Continued)

\begin{tabular}{|c|c|c|c|c|}
\hline \multirow{2}{*}{\multicolumn{2}{|c|}{ TARGET }} & MAJOR FINDINGS & YEAR & REFERENCE \\
\hline & & \multicolumn{3}{|l|}{$A \beta 1-40$ and $A \beta 1-42$} \\
\hline & $\begin{array}{l}\text { Calcium homeostasis; } \\
\text { Cytokine release; Lactate } \\
\text { secretion; Mitochondrial } \\
\text { metabolism; Oxidative } \\
\text { stress; Aß production }\end{array}$ & $\begin{array}{l}\text { AD astrocytes manifest } \\
\text { hallmarks of disease pathology, } \\
\text { including increased Aß production, } \\
\text { altered cytokine release, } \\
\text { and dysregulated } \\
\mathrm{Ca} 2+\text { homeostasis. }\end{array}$ & 2017 & Oksanen et al [82] \\
\hline & $\begin{array}{l}\text { LC-MS/MS; Biomarker; } \\
\text { Proteomics }\end{array}$ & $\begin{array}{l}\text { Alpha-1-acid glycoprotein } \\
\text { (ORM1) was decreased in } \\
\text { the culture media of } \\
\text { AD-iPSCs-derived neurons, } \\
\text { consistent with previous } \\
\text { observations for AD patient } \\
\text { cerebrospinal fluid, thus } \\
\text { validating our new strategy. }\end{array}$ & 2017 & Shirotani et al [113] \\
\hline & $\begin{array}{l}\text { hiPSC-derived } \\
\text { astrocyte model }\end{array}$ & $\begin{array}{l}\text { Chemically defined and highly } \\
\text { efficient model provides } \\
>95 \% \text { homogeneous } \\
\text { populations of human } \\
\text { astrocytes within } 30 \text { days } \\
\text { of differentiation } \\
\text { from cortical NPCs. }\end{array}$ & 2017 & Jones et al [51] \\
\hline & $\begin{array}{l}\text { A } \beta ; \text { Neurotoxicity; } \\
\text { PS1-A246E mutation }\end{array}$ & $\begin{array}{l}\text { iPSCs lines were differentiated } \\
\text { into neuronal precursors } \\
\text { (iPSCs-NPCs) and neurons } \\
\text { that were subjected to AB } \\
\text { toxicity assays. Neurons } \\
\text { derived from the FAD } \\
\text { patient have a higher } \\
\text { susceptibility to AB1-42 } \\
\text { oligomers compared with } \\
\text { neurons coming from } \\
\text { healthy and SAD individuals. }\end{array}$ & 2017 & Armijo et al [5] \\
\hline & $\begin{array}{l}\text { Neuroprotective } \\
\text { activity; Apigenin }\end{array}$ & $\begin{array}{l}\text { The iPSCs-derived AD neurons } \\
\text { demonstrated a hyper-excitable } \\
\text { calcium signaling phenotype, } \\
\text { elevated levels of nitrite, } \\
\text { increased cytotoxicity and } \\
\text { apoptosis, reduced neurite } \\
\text { length and increased } \\
\text { susceptibility to inflammatory } \\
\text { stress challenge from activated } \\
\text { murine microglia, in } \\
\text { comparison to control neurons. }\end{array}$ & 2016 & Balez et al [8] \\
\hline & $\begin{array}{l}\text { Cellular model; Synaptotoxic } \\
\text { effects of } A \beta\end{array}$ & $\begin{array}{l}\text { Upon long-term cultivation, } \\
\text { purified cells differentiated } \\
\text { into mature neurons exhibiting } \\
\text { the generation of action } \\
\text { potentials and excitatory } \\
\text { glutamatergic and inhibitory } \\
\text { GABAergic synapses. } \\
\text { Most interestingly, } \\
\text { these iPSCs-derived human } \\
\text { neurons were strongly } \\
\text { susceptible to the } \\
\text { synaptotoxic actions of Aß. }\end{array}$ & 2015 & Nieweg et al [79] \\
\hline & $\begin{array}{l}\text { Neurotoxicity; Non-toxic } \\
\text { mutants of } A \beta 42 ;\end{array}$ & $\begin{array}{l}\text { The non-toxic mutants of } \\
\text { A } 342 \text { without the "toxic" } \\
\text { turn could prevent the } \\
\text { propagation process of } \\
\text { the toxic conformer of } \\
\text { A } 442 \text { resulting in suppression } \\
\text { of the formation of } \\
\text { the toxic oligomers. }\end{array}$ & 2013 & Izuo et al [49] \\
\hline & Disease model & $\begin{array}{l}\text { A } \beta \text { oligomers accumulated in } \\
\text { iPSCs-derived neurons and } \\
\text { astrocytes in cells from } \\
\text { patients with a familial } \\
\text { APP-E693 } \Delta \text { mutation } \\
\text { and SAD, leading to } \\
\text { endoplasmic reticulum } \\
\text { (ER) and oxidative stress. }\end{array}$ & 2013 & Kondo et al [55] \\
\hline
\end{tabular}


Table 1 Update of all publications until now involving iPSCs approach in Alzheimer's disease (Continued)

\begin{tabular}{|c|c|c|c|c|}
\hline \multicolumn{2}{|l|}{ TARGET } & \multirow[b]{2}{*}{ 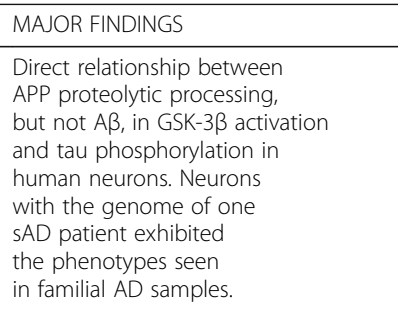 } & \multirow{2}{*}{$\begin{array}{l}\text { YEAR } \\
2012\end{array}$} & \multirow{2}{*}{$\begin{array}{l}\text { REFERENCE } \\
\text { Israel et al [48] }\end{array}$} \\
\hline & $\begin{array}{l}\text { Duplication of the } \\
\text { A APP (Dp) }\end{array}$ & & & \\
\hline & $\begin{array}{l}\text { Drug evaluation; Preclinical; } \\
\text { Tissue therapy; } \\
\text { PD; DM; DMD }\end{array}$ & $\begin{array}{l}\text { Each iPSCs line exhibited } \\
\text { an intense alkaline } \\
\text { phosphatase activity, } \\
\text { expression of pluripotent } \\
\text { markers, and the potential } \\
\text { to differentiate into } \\
\text { all three embryonic germ layers. }\end{array}$ & 2012 & Jang et al [50] \\
\hline \multirow[t]{6}{*}{ DOES NOT SPECIFY } & $\begin{array}{l}\text { Drug screening; } \\
\text { Parkinsonism; Tauopathies; } \\
\text { Triple MAPT-mutant }\end{array}$ & $\begin{array}{l}\text { Mutant neurons expressed } \\
\text { pathogenic } 4 R \text { and } \\
\text { phosphorylated TAU, } \\
\text { endogenously triggered } \\
\text { TAU aggregation, and had } \\
\text { increased electrophysiological activity. }\end{array}$ & 2018 & García-León et al [37] \\
\hline & $\begin{array}{l}\text { DS; Hsa21 trisomy; A } ; \\
\text { Cortical neurogenesis; } \\
\text { Tau phosphorylation }\end{array}$ & $\begin{array}{l}\text { Cortical neuronal differentiation } \\
\text { shows that an increased APP } \\
\text { gene dosage is responsible } \\
\text { for increased } \beta \text {-amyloid } \\
\text { production, altered A } A 42 / 40 \\
\text { ratio, and deposition of } \\
\text { the pyroglutamate } \\
\text { (E3)-containing amyloid } \\
\text { aggregates, but not for } \\
\text { several tau-related AD } \\
\text { phenotypes or increased apoptosis. }\end{array}$ & 2018 & Ovchinnikov [85] et al \\
\hline & $\begin{array}{l}\text { 3D culture; Bioinformatics; } \\
\text { Proteomic }\end{array}$ & $\begin{array}{l}\text { Similar analysis of post-mortem } \\
\text { AD brain tissue revealed } \\
\text { significant alteration in } \\
\text { proteins involved in oxidative } \\
\text { stress, neuro-inflammation, } \\
\text { along with proteins } \\
\text { related to axonal injury. }\end{array}$ & 2018 & Chen et al [21] \\
\hline & Leptomeningeal cell; Postmortem & $\begin{array}{l}\text { Leptomeningeal-derived hiPSCs } \\
\text { lines can be generated } \\
\text { from fresh and frozen } \\
\text { leptomeninges, are pluripotent, } \\
\text { and retain the karyotype } \\
\text { of the starting cell population. }\end{array}$ & 2018 & Rose et al [96] \\
\hline & $\begin{array}{l}\text { SORL1 expression; Null, } \\
\text { one, or two copies } \\
\text { of the APOE4 allele }\end{array}$ & $\begin{array}{l}\text { Reduced SORL1 expression } \\
\text { only in NSCs of a patient } \\
\text { carrying two copies of } \\
\text { APOE4 allele with increased } \\
\text { A } / \text { SORL1 localization along } \\
\text { the degenerated neurites. } \\
\text { SORL1 binding to APP } \\
\text { was largely compromised; } \\
\text { this could be almost completely } \\
\text { reversed by } \gamma \text {-secretase } \\
\text { (but not } \beta \text {-secretase) } \\
\text { inhibitor treatment. }\end{array}$ & 2017 & Zollo et al [142] \\
\hline & $\begin{array}{l}\text { PD; Cortical neurons; } \\
\text { Macrophage; Microglia; } \\
\text { Neuroinflammation }\end{array}$ & $\begin{array}{l}\text { Co-cultures retain neuronal } \\
\text { maturity and functionality } \\
\text { for many weeks. Co-culture } \\
\text { microglia express key } \\
\text { microglia-specific markers } \\
\text { and neurodegenerative } \\
\text { disease-relevant genes, } \\
\text { develop highly dynamic } \\
\text { ramifications, and are } \\
\text { phagocytic. Upon } \\
\text { activation, they become } \\
\text { more amoeboid, releasing } \\
\text { multiple } \\
\text { microglia-relevant cytokines. }\end{array}$ & 2017 & Haenseler et al [42] \\
\hline
\end{tabular}


Table 1 Update of all publications until now involving iPSCs approach in Alzheimer's disease (Continued)

TARGET
AICD; APP; CTF; AB;p3 peptide

PBMCs; Yamanaka factors

Down syndrome; $A \beta$ vermectin; Phenotypic screening; Selamectin

APP; Aß42; BACE2; AB DS; ETS2; RCAN1; TMED10

hTFAM; Oxidative stress; mtDNA

Gene-corrected version; Substituting mutation with wild-type sequence A79V mutation in PSEN1

HLC; Gene CR1

Episomal plasmids; HLC; Missense mutation TREM2

MAJOR FINDINGS
The $42: 40$ ratio was highest
for $A \beta^{\prime}$, followed by $A \beta$
and then p3. Mass
spectrometry analysis
of APP intracellular domains
revealed differential processing
of APP-C 83, APP-C 89 , and
APP-C99 by $\gamma$-secretase
already at the $\varepsilon$-cleavage stage.

The transgene-free iPSCs

line showed pluripotency

verified by immunofluorescent

staining for pluripotency

markers, and the iPSCs line

was able to differentiate

into the 3 germ layers in

vivo. The iPSCs line also

showed normal karyotype.

The authors identified the

avermectins, commonly

used as anthelmintic, as

compounds that increase

the relative production of

short $A B$ peptides at the

expense of longer, potentially

more toxic peptides. Further

studies demonstrated that

this effect is not due to an

interaction with the core

$\gamma$-secretase responsible

for $A \beta$ production.

In vitro generated DS neural cells have abnormal metabolism

of $A \beta$ manifested by increased

secretion and accumulation of

$A \beta$ granules of $A \beta 42$ pathological

isoform with upregulated

expression of the APP gene.

Expression of hTFAM significantly

improved cognitive function,

reducing accumulation of

both 8-oxoguanine, an

oxidized form of guanine,

in mtDNA and intracellular

$A \beta$ in $3 \times T g-A D$ mice and

increasing expression

of transthyretin, known

to inhibit $A \beta$ aggregation.

The reported A79V-GC-iPSCs

line is a very useful resource

in combination with the

A79V-iPSCs line in order to

study pathological cellular

phenotypes related to this

particular mutation.

The iPSCs retained the CR1

$\mathrm{CNV}$, and comparative

transcriptome analyses

with the human ESCs line

$\mathrm{H} 1$ revealed a Pearson

correlation of 0.956 for

AD1-CR10 and 0.908

for AD1-CR14.

Human lymphoblast cells

from a female patient

possessing the mis-sense

mutation TREM2 p.R47H

were used to generate

integration-free iPSCs

employing episomal

plasmids expressing

OCT4, SOX2, NANOG,

LIN28, C-MYC and L-MYC.

\section{YEAR}

REFERENCE

2017

Siegel et al [114]

2017 Zhang et al [140]

2017

Brownjohn et al [16]

2017

Dashinimaev et al [23]

2016

Oka et al [81] 
Table 1 Update of all publications until now involving iPSCs approach in Alzheimer's disease (Continued)

\begin{tabular}{|c|c|c|c|c|}
\hline \multicolumn{2}{|l|}{ TARGET } & \multirow[b]{2}{*}{$\begin{array}{l}\text { MAJOR FINDINGS } \\
\text { Integration-free CytoTune-iPS } \\
\text { Sendai Reprogramming } \\
\text { factors were introduced to } \\
\text { PBMC to convert them to } \\
\text { iPSCs without retention of } \\
\text { virus. Three germ layer } \\
\text { differentiation was induced } \\
\text { to demonstrate the } \\
\text { pluripotency of these iPSCs. }\end{array}$} & \multirow{2}{*}{$\begin{array}{l}\text { YEAR } \\
2016\end{array}$} & \multirow{2}{*}{$\begin{array}{l}\text { REFERENCE } \\
\text { Lee et al [59] }\end{array}$} \\
\hline & PBMC; Memory deficit & & & \\
\hline & $\begin{array}{l}\text { Disease model; Human } \\
\text { lymphoblast cells; } \\
\text { TREM2 p.R47H variant }\end{array}$ & $\begin{array}{l}\text { Human lymphoblast cells } \\
\text { from a male patient } \\
\text { expressing the TREM2p.R47H } \\
\text { variant were used to generate } \\
\text { integration-free iPS cells } \\
\text { employing episomalplasmids } \\
\text { expressing OCT4, SOX2, NANOG, } \\
\text { LIN28, C-MYC and L-MY }\end{array}$ & 2016 & Schroter et al [99] \\
\hline & Apoptosis; Kinase inhibitors; TRAlL & $\begin{array}{l}\text { Wortmannin resulted in } \\
\text { disappearance of } \\
\text { phosphorylated AKT and } \\
\text { activation of the main effector } \\
\text { caspase-3 in iPSCs. These results } \\
\text { clearly demonstrate for the } \\
\text { first time that PISK-AKT } \\
\text { represents a highly essential } \\
\text { survival-signaling pathway in iPSCs. }\end{array}$ & 2016 & Hossini et al [45] \\
\hline & DS; MSC; Amniotic fluid & $\begin{array}{l}\text { DS-iPSC derived neural } \\
\text { cells can serve as an ideal } \\
\text { cellular model of DS and AD } \\
\text { and have potential for } \\
\text { high-throughput screening } \\
\text { of candidate drugs. Bdph may } \\
\text { benefit DS or AD treatment } \\
\text { by scavenging AB } \\
\text { aggregates and NFTs. }\end{array}$ & 2015 & Chang et al [19] \\
\hline & 3D culture; Mechanotransduction & $\begin{array}{l}3 \mathrm{D} \text { in vitro model has } \\
\text { higher resemblance to the } \\
\mathrm{AD} \text { pathology than } \\
\text { conventional } 2 \mathrm{D} \text { cultures } \\
\text { and could be used in } \\
\text { further studies of the disease. }\end{array}$ & 2014 & Zhang et al [139] \\
\hline & $A \beta ;$ Glutamatergic; In vitro model & $\begin{array}{l}\text { Administration of such } \\
A \beta \text { oligomers yielded } \\
\text { signs of the disease, including } \\
\text { cell culture age-dependent } \\
\text { binding of } A \beta \text { and cell } \\
\text { death in the glutamatergic } \\
\text { populations. A } \beta \text {-induced } \\
\text { toxicity was selective for } \\
\text { glutamatergic rather than } \\
\text { GABAeric neurons } \\
\text { present in our cultures. }\end{array}$ & 2014 & Vazin et al [125] \\
\hline & GCSF; $A \beta$-induced & $\begin{array}{l}\text { Demonstrate an improvement } \\
\text { of memory and } \\
\text { neurobehavioral function } \\
\text { with GCSF in } \\
A \beta \text {-induced } A D \text { model in rats. }\end{array}$ & 2013 & Prakash et al [92] \\
\hline & $\begin{array}{l}\text { Drug evaluation; Forebrain } \\
\text { marker; Neocortical markers }\end{array}$ & $\begin{array}{l}\text { The iPSCs cell-derived neuronal } \\
\text { cells also expressed APP, } \\
\beta \text {-secretase, and } \gamma \text {-secretase } \\
\text { components, and were capable } \\
\text { of secreting A } A \text { into the } \\
\text { conditioned media. A } \\
\text { production was inhibited } \\
\text { by } \beta \text {-secretase inhibitor, } \\
\gamma \text {-secretase inhibitor (GSI), } \\
\text { and an NSAID; however, } \\
\text { there were different } \\
\text { susceptibilities to all } \\
\text { three drugs between } \\
\text { early and late } \\
\text { differentiation stages. }\end{array}$ & 2011 & Yahata et al [133] \\
\hline
\end{tabular}


and even personalized therapeutics based on individual's genetics [94].

\section{Future directions}

With the advancement of research using the iPSCs, the customization of the treatment for patients with $\mathrm{AD}$ is possible, reaching new insights associated with the pathogenesis and discovery of new drugs for the treatment and/or prevention, which is economically impractical at present [83]. The treatment is individualized based on the behavior of the cellular model for possibly defining the AD subgroups [83]. At present, we can model in vitro diseases to allow patient-specific therapies from newly derived AD-iPSCs to be used by considering the appropriate characterization of $\mathrm{AD}$ patient groups through genetic profiles and biomarkers [83].

In addition, iPSCs have some limitations. One can consider the immature and fetal population of neurons that are obtained from the iPSCs that model the AD in case of an illness of the aging [69, 73, 118, 127]. Therefore, there is a possibility to express a mutant form of LMNA, which is known to cause premature aging [46].

The challenges in the enhancement of iPSCs are directly related to modeling protocols. In iPSCs, we can highlight the level of maturity of the neurons, lack of efficient protocols to generate microglia, and few protocols of 3D differentiation that appropriately mimic the in vivo environment of the brain [107]. Now, to generate and differente iPSCs are still a time-consuming and expensive processes; however, with the improvement and development of new protocols, iPSCs can be used from an individual to direct their appropriate treatment through personalized medicine, improving the patient's life [46].
During the formation of iPSCs, there are a concern about introducing harmful mutations. Therefore, new genome editing techniques, such as the clustered regularly interspaced short palindromic repeats (CRISPR)-associated protein 9 (Cas9) nuclease system, reduce the risk of introduction and spread of undesired mutations $[134,110]$. Paquet et al. [86] accurately and efficiently generated both homozygous and heterozygous dominant AD-causing mutations using CRISPR/Cas9 [110].

Essentially, neurodifferentiated cells from iPSCs exhibit the pathological characteristics of an individual with $\mathrm{AD}$ in less than two months, demonstrating that cultured cells are more susceptible to display the disease characteristics than those that occur in a patient's brain. Moreover, it is not known whether one or two differentiated cell types from iPSCs may represent the complicated disease phenotype [134].

Another limitation of iPSCs is the fact that they represent models in two dimensions, thus lacking cellular diversity, having structural complexity, and presenting physical architecture in vivo. Therefore, a fundamental approach for the development of a physiologically relevant model is to make a three-dimensional (3D) model of the neurons and glia [4,32], revealing heterogeneous and naturally organized cellular models [4]. Normal cortical folding [66], microcephaly [56], and lissencephaly [11] are some successful organoids used to model neurodevelopmental processes and diseases [4]. Neurodegenerative disease models are still scarce; they can give new insight to model AD [4]. According to our literature survey, some authors are already using organoids in $\mathrm{AD}$ research, which originate from iPSCs [1, 102, 116, 117]. Therefore, defined radial glial cells can be obtained using these organoids; these cells are crucial in brain development and function, as well

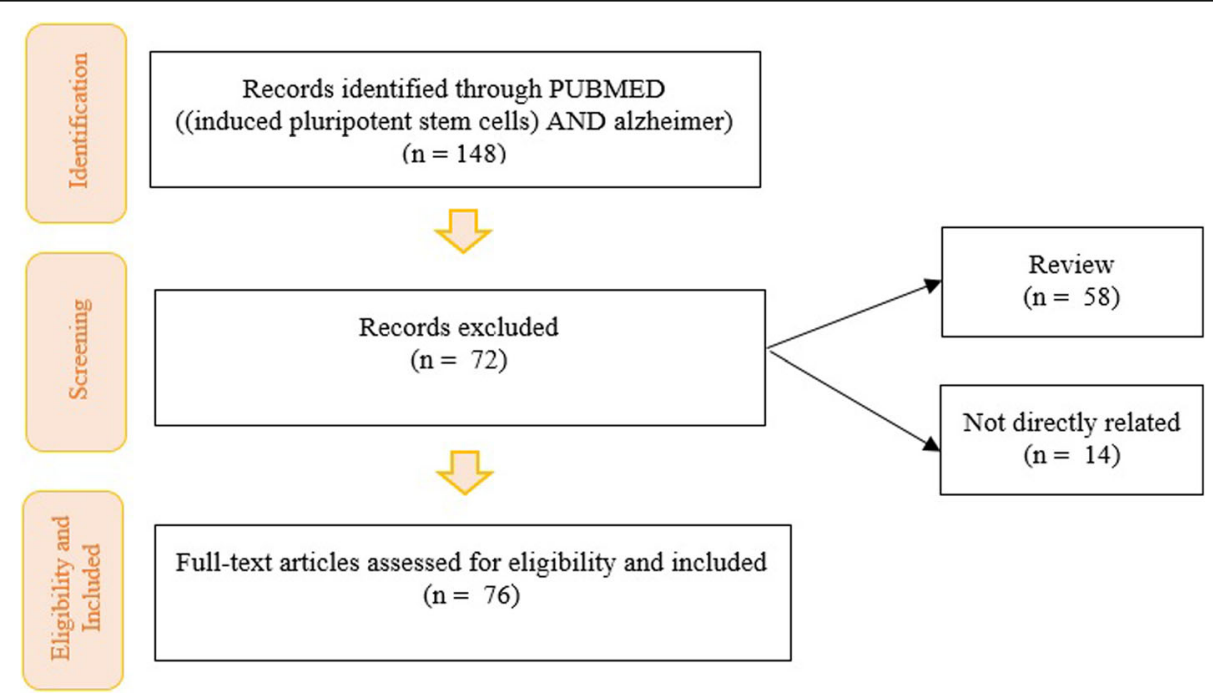

Fig. 1 Flow diagram with the terms searched in the search engine 
as associated with the organization and morphology similar to the developing human cortex $[4,93]$. This model has made considerable contributions over time. Thus, supporting cells that develop along the first neurons can be crucial in modeling the onset and progression of the disease $[4,95]$.

Along with the progressive neurodegeneration of patients with $\mathrm{AD}$, memory and the ability to learn and perform daily activities are also impaired over time. In an aging society is necessary and urgent to develop an efficient drug to treat $\mathrm{AD}$, thus clinical $\mathrm{AD}$ may need to be reclassified into different subtypes, and the prediction of drug responsiveness may be possible based on the different subtypes [55, 47].

Considering that therapies for AD are mostly palliative, a great deal of effort is made by the scientific community to discover a drug; however, several promising candidate drugs have failed in recent clinical trials [20]. Semagacestat, for example, is a potential nontransitional state analog of $\gamma$-secretase inhibitor (GSI). All GSI studies for AD, including Semagacestat, were unsuccessful $[112,109]$. Arguments against the efficacy of reducing $\mathrm{A} \beta$ levels in the brain are based on the results obtained while aiming a therapy for $\operatorname{AD}[12,33,53,109]$; the expected effect was exactly the opposite, considering that Semagacestat and another potential GSI Avagacestat worsened the cognitive decline [22, 26, 109].

Recently, quantifying small residual peptides, Tagami et al. [109], addressed the effects of Semagacestat on PS/ g-secretase activity, generated during sequential cleavages upon $\mathrm{A} \beta$ production. The authors demonstrated seemingly contradictory actions of Semagacestat, by decreasing levels of extracellular $A \beta$ and intracellular amyloid protein precursor intracellular cytoplasmic domain along with increased bAPP-C-terminal fragment stubs. These Semagacestat effects are clearly different from those caused by a loss of functional PSs. According to the authors, Semagacestat is a pseudo-GSI and may inhibit the liberation of product peptides by g-secretase (g-byproducts) from the membrane to the soluble space. This allows g-byproducts to accumulate in living cells. A comprehensive assessment related to g-secretase activity will allow the discovery of clinical application of g-secretase-modulating compounds [109].

From AD diagnosis, an individual has four to five years of life span. Neuroreplaced therapies will not compensate for the neuronal loss but may be used to improve existing circuits temporarily, contributing to cognitive function and quality of life [30]. Cell replacement therapy has been the most challenging because of the multifactorial nature of AD. Earlier studies in animal models with $\mathrm{AD}$ have shown that the transplantation of neural stem cells can improve cognition, reduce neuronal loss, and increase synaptic plasticity. This is probably because of the mechanisms that are involved in neuroprotection and trophic support rather than those involved in neuronal substitution [20].

Future studies with iPSCs need to define the cell type and which cell type is impacted in a disease phenotype $[24,35,40]$. If the genetic identity of a natural cell is defined, it is possible to correlate with the modified cell in vitro. Similar studies are already proposed regarding the retina $[105,75]$.

With the increased genetic information, it becomes a growing priority to translate these genotypes into their functional biological results. The formation of subtypes of neurons can contribute to the evaluation of variants within discrete cell populations, defining specific genetic contributions to disease within each cell class [107].

The involvement of the cell type in the disease, with the possibility of modulating a specific gene expression profile, will help monitor the effect on downstream pathway members and consequently allow the modification of the pathways associated with the disease by modifying the proposed disease-relevant pathways. The evaluation of the phenotypic results of these alterations will show the biological effects of the gene expression, classifying whether the gene is relevant to the disease or not [108].

The prevalence of $\mathrm{AD}$ is higher in women, but in men the congenital decline is more severe and early $[57,110]$. Hormonal and metabolic differences in the brain may explain these distinctions between the sexes $[138,110]$. The study on the sexual dimorphism of microglia phenotype, for example, in the cortex and cerebellum, has strengthened [106, 111, 103, 7]. According to Streit et al. [119], microglia may be involved through the "microglia dysfunction hypothesis". Therefore, to elucidate the influence of sex and its contribution to neuroinflammation in the $\mathrm{AD}$, future studies may include endogenous microglia and inflammation as a phenotype in chimeric models [110].

Goldstein et al. [39] pointed some suggestions for future research, such as working in isogenic systems, which are described by Woodruff et al. [129], considering the known genome variability and human physiology. In addition, working on cell -nes that have been completely sequenced and determining a true diploid sequence to the level of the genome described to date have been suggested [63,39]. Because of the complex nature of the pathophysiology of $\mathrm{AD}$, a multimodal approach may be necessary, incorporating the pharmacological segmentation of the pathology, stimulation of endogenous neurogenesis and synaptogenesis, and exogenous neuroreplacement [30].

Regarding sporadic AD, a greater challenge exists to elucidate the factors that result in the disease. It is known that there is a hereditary component and that 
each individual with its unique genetic background has variants that may predispose or protect for the disease. Therefore, the research seeks to discover the genetic contribution to the $\mathrm{AD}$ if there are phenotypic consequences in an individual with a genetic background that contains genetic variants of risk [137]. In this manner, possible paths can be disclosed, and in the future may be used to determine the factors that cause $\mathrm{AD}$ and to test new possible therapeutics strategies [137]. Yang et al. [134] highlighted that an appropriate control group needs to be selected; iPSCs derived from healthy individuals or family members may have totally different genetic background compared with those from individuals with AD [134].

Valuable findings have already been obtained regarding the development of AD; however, several studies still need to elucidate its effects. For example, new information related to genetic variants in individual genomes and their influence on the neuronal phenotype will facilitate to identify the chance to developing $A D$ through the identification of molecular and biochemical phenotypes caused by these genetic variants [137]. This 3D approach can reveal the connection between neurons and glia, and these genetic factors can be advantageous to drugs discovery of when the supporting cells are crucial, or the route of interest is unknown $[4,32]$.

\section{Conclusion}

The AD field of research has received valuable contributions from iPSC models. Considering that the iPSC technique is relatively recent, discovered in 2006, it is important to recognize associated advances obtained so far in $\mathrm{AD}$ research. The possibility to study neurons from a patient with $\mathrm{AD}$ in a culture dish allows observation of relevant cellular phenotypes and behaviors, following the earliest events in dementia. These research models have allowed the observation of direct molecular effects of FAD mutations and genetic risk variants, which may lead to more efficacious treatments targeting this devastating disorder.

\section{Abbreviations}

AD: Alzheimer's disease; ApoE4: Apolipoprotein-E4; APP: Amyloid precursor protein; ASM: Acid sphingomyelinase; A $\beta$ : Amyloid-beta; BFCNs: Basal forebrain cholinergic neurons; Cdk5: Cyclin-dependent kinase 5; CNS: Central Nervous System; CTF: C-terminal fragment; DIAN: Dominantly Inherited Alzheimer Network; DM: Diabetes mellitus; DMD: Duchenne type muscular dystrophy; ESCs: Embryonic stem cells; FAD: Familial AD; GCSF: Granulocyte colony stimulating factor; GSI: $\gamma$-secretase inhibitors; GSM: $\gamma$-secretase modulator; HCE: Human chemical exposome; HLC: Human lymphoblast cells; hTFAM: Human mitochondrial transcriptional factor A; IMGLs: Human microglial-like cells; iPSCs: Induced pluripotent stem cells; MSC: Mesenchimal stem cells; mtDNA: Mitochondrial DNA; NFTs: Neurofibrillary tangles.; nonTSA: Non-transition state analog; NPCs: Neural progenitor cells; PBMCs: Peripheral blood mononuclear cells; PD: Parkinson's disease; PS1: Presenilin-1; PS2: Presenilin-2; SAD: Sporadic AD; sAPPa: Soluble amyloid precursor protein-alpha
}

\section{Acknowledgements}

We thank Pandurata Alimentos Ltda for financial support to the English editing of text. FM is the recipient postdoctoral grant from Coordenação de Aperfeiçoamento de Pessoal de Nível Superior - Brasil (Capes).

\section{Funding}

This study was financed in part by the Coordenação de Aperfeiçoamento de Pessoal de Nível Superior - Brasil (CAPES) - Finance Code 001.

\section{Availability of data and materials}

Not applicable.

\section{Authors' contributions}

FM and DRM drafted the manuscript and wrote the article. DCM and JCDC participated in its design and coordination and helped to draft the manuscript. All authors read and approved the final manuscript.

Ethics approval and consent to participate

Not applicable.

\section{Consent for publication}

Not applicable.

\section{Competing interests}

The authors declare that they have no competing interests.

\section{Publisher's Note}

Springer Nature remains neutral with regard to jurisdictional claims in published maps and institutional affiliations.

Received: 30 August 2018 Accepted: 9 January 2019

Published online: 06 February 2019

\section{References}

1. Abud EM, Ramirez RN, Martinez ES, Healy LM, Nguyen $\mathrm{CHH}$, Newman SA, Yeromin AV, et al. iPSC-Derived Human Microglia-like Cells to Study Neurological Diseases. Neuron. 2017;94(2):278-293.e9. https://doi.org/10 1016/j.neuron.2017.03.042.

2. Akhtar MW, Sanz-Blasco S, Dolatabadi N, Parker J, Chon K, Lee MS, Soussou W, et al. Elevated glucose and oligomeric $\beta$-amyloid disrupt synapses via a common pathway of aberrant protein S-nitrosylation. Nat Commun. 2016;7: 10242. https://doi.org/10.1038/ncomms10242.

3. Alzheimers Association. 2015 Alzheimer's disease facts and figures. Alzheimers Dement. 2015;11:332.

4. Arber C, Lovejoy C, Wray S. Stem cell models of Alzheimer's disease: progress and challenges. Alzheimers Res Ther. 2017;9(1):42. Published 2017 Jun 13. https://doi.org/10.1186/s13195-017-0268-4.

5. Armijo E, Gonzalez C, Shahnawaz M, Flores A, Davis B, Soto C. Increased susceptibility to $A \beta$ toxicity in neuronal cultures derived from familial Alzheimer's disease (PSEN1-A246E) induced pluripotent stem cells. Neurosci Lett. 2017;639:74-81. https://doi.org/10.1016/j.neulet.2016.12.060.

6. Avramopoulos D. Genetics of Alzheimer's disease: recente advances. Genome Med. 2009;1:34

7. Bakkour A, Morris JC, Wolk DA, Dickerson BC. The effects of aging and Alzheimer's disease on cerebral cortical anatomy: specificity and differential relationships with cognition. Neuroimage. 2013;76:332-44. https://doi.org/ 10.1016/j.neuroimage.2013.02.059 Epub 2013 Mar 16.

8. Balez R, Steiner N, Engel M, Muñoz SS, Lum JS, Wu Y, Wang D, Vallotton P, Sachdev $P$, et al. Neuroprotective effects of apigenin against inflammation, neuronal excitability and apoptosis in an induced pluripotent stem cell model of Alzheimer's disease. Sci Rep. 2016;6:31450. https://doi.org/10.1038/ srep31450.

9. Ben Halima S, Mishra S, Raja KMP, Willem M, Baici A, Simons K, Brüstle O, Koch P, Haass C, Caflisch A, Rajendran L. Specific Inhibition of $\beta$-Secretase Processing of the Alzheimer DiseaseAmyloid Precursor Protein. Cell Rep. 2016;14(9):2127-41. https://doi.org/10.1016/j.celrep.2016.01.076.

10. Berchtold NC, Cotman CW. Evolution in the conceptualization of dementia and Alzheimer's disease: Greco-Roman period to the 1960s. Neurobiol Aging. 1998;19(3):173-89.

11. Bershteyn M, Nowakowski TJ, Pollen AA, Di Lullo E, Nene A, Wynshaw-Boris A, et al. Human iPSC-derived cerebral organoids model cellular features of 
lissencephaly and reveal prolonged mitosis of outer radial glia. Cell Stem Cell. 2017:20(4):435-49.e4.

12. Blennow $K$, Zetterberg $H$, Haass $C$, Finucane $T$. Semagacestat's fall: where next for AD therapies? Nat. Med., 19 (2013), pp. 1214-1215.

13. Birnbaum JH, Wanner D, Gietl AF, Saake A, Kündig TM, Hock C, Nitsch RM, Tackenberg C. Oxidative stress and altered mitochondrial protein expression in the absence of amyloid- $\beta$ and tau pathology in iPSC-derived neurons from sporadic Alzheimer's disease patients. Stem Cell Res. 2018;27:121-30. https://doi.org/10.1016/j.scr.2018.01.019.

14. Brookhouser N, Zhang P, Caselli R, Kim JJ, Brafman DA. Generation and characterization of human induced pluripotent stem cell (hiPSC) lines from an Alzheimer's disease (ASUi003-A) and non-demented control (ASUi004-A) patient homozygous for the Apolipoprotein e4 (APOE4) risk variant. Stem Cell Res. 2017;25:266-9. https://doi.org/10.1016/j.scr.2017.07.003.

15. Brookhouser N, Zhang P, Caselli R, Kim JJ, Brafman DA. Generation and characterization of human induced pluripotent stem cell (hiPSC) lines from an Alzheimer's disease (ASUi001-A) and non-demented control (ASUi002-A) patient homozygous for the Apolipoprotein e4 (APOE4) risk variant. Stem Cell Res. 2017;24:160-3. https://doi.org/10.1016/j.scr.2017.06.003.

16. Brownjohn PW, Smith J, Portelius E, Serneels L, Kvartsberg H, De Strooper B, Blennow K, et al. Phenotypic Screening Identifies Modulators of Amyloid Precursor Protein Processing in Human Stem Cell Models of Alzheimer's Disease. Stem Cell Reports. 2017;8(4):870-82. https://doi.org/10.1016/j. stemcr.2017.02.006.

17. Brunholz S, Sisodia S, Lorenzo A, Deyts C, Kins S, Morfini G. Axonal transport of APP and the spatial regulation of APP cleavage and function in neuronal cells. Exp Brain Res. 2012;217:353-64.

18. Cha MY, Kwon YW, Ahn HS, Jeong H, Lee YY, Moon M, Baik SH, Kim DK, Song $\mathrm{H}$, et al. Protein-Induced pluripotent Stem Cells Ameliorate Cognitive Dysfunction and Reduce A $B$ Deposition in a Mouse Model of Alzheimer's Disease. Stem Cells Transl Med. 2017;6(1):293-305. https://doi.org/10.5966/ sctm.2016-0081.

19. Chang CY, Chen SM, Lu HE, Lai SM, Lai PS, Shen PW, Chen PY, Shen Cl, et al. $\mathrm{N}$-butylidenephthalide attenuates Alzheimer's disease-like cytopathy in Down syndrome induced pluripotent stem cell-derived neurons. Sci Rep. 2015;5:8744. https://doi.org/10.1038/srep08744.

20. Chen WW, Blurton-Jones M. Concise review: can stem cells be used to treat or model Alzheimer's disease? Stem Cells. 2012;30(12):2612-8.

21. Chen M, Lee HK, Moo L, Hanlon E, Stein T, Xia W. Common proteomic profiles of induced pluripotent stem cell-derived three-dimensional neurons and brain tissue from Alzheimer patients. J Proteome. 2018;182:21-33. https://doi.org/10.1016/j.jprot.2018.04.032.

22. Coric V, van Dyck CH, Salloway S, Andreasen N, Brody M, Richter RW, Soininen H, Thein S, Shiovitz T, Pilcher G, Colby S, Rollin L, Dockens R, Pachai C, Portelius E, Andreasson U, Blennow K, Soares H, Albright C, Feldman HH, Berman RM.Safety and tolerability of the $\gamma$-secretase inhibitor avagacestat in a phase 2 study of mild to moderate Alzheimer disease. Arch Neurol. 2012;69(11):1430-40.

23. Dashinimaev EB, Artyuhov AS, Bolshakov AP, Vorotelyak EA, Vasiliev AV. Neurons Derived from Induced pluripotent Stem Cells of Patients with Down Syndrome Reproduce Early Stages of Alzheimer's Disease Type Pathology in vitro. J Alzheimers Dis. 2017;56(2):835-47. https://doi.org/10. 3233/JAD-160945.

24. Defelipe J, Lopez-Cruz PL, Benavides-Piccione R, Bielza C, Larranaga P, Anderson S, Burkhalter A, Cauli B, Fairen A, Feldmeyer D, Fishell G, Fitzpatrick D, Freund TF, Gonzalez-Burgos G, Hestrin S, Hill S, Hof PR, Huang J, Jones EG, Kawaguchi Y, Kisvarday Z, Kubota Y, Lewis DA, Marin O, Markram H, McBain CJ, Meyer HS, Monyer H, Nelson SB, Rockland K, Rossier $J$, Rubenstein JLR, Rudy B, Scanziani M, Shepherd GM, Sherwood CC, Staiger JF, Tamas G, Thomson A, Wang Y, Yuste R, Ascoli GA. New insights into the classification and nomenclature of cortical GABAergic interneurons. Nature Reviews Neuroscience. 2013; 14:202-216. PMID: 23385869.

25. Dimos JT, Rodolfa KT, Niakan KK, Weisenthal LM, Mitsumoto H, Chung W, Croft GF, Saphier G, Leibel R, Goland R, et al. Induced pluripotent stem cells generated from patients with ALS can be differentiated into motor neurons. Science. 2008;321:1218-21.

26. Doody RS, Raman R, Farlow M, Iwatsubo T, Vellas B, Joffe S, Kieburtz K, He F, Sun X, Thomas RG, Aisen PS; Alzheimer's Disease Cooperative Study Steering Committee, Siemers E, Sethuraman G, Mohs R; Semagacestat Study Group. A phase 3 trial of semagacestat for treatment of Alzheimer's disease. N Engl J Med. 2013;369(4):341-50. https://doi.org/10.1056/NEJMoa1210951
27. Dragunow $M$. The adult human brain in preclinical drug development. Nat Rev Drug Discov. 2008;7(8):659-66.

28. Duan L, Bhattacharyya BJ, Belmadani A, Pan L, Miller RJ, Kessler JA. Stem cell derived basal forebrain cholinergic neurons from Alzheimer's disease patients are more susceptible to cell death. Mol Neurodegener. 2014;9:3. https://doi.org/10.1186/1750-1326-9-3.

29. Duff K, Suleman F. Transgenic mouse models of Alzheimer's disease: how useful have they been for therapeutic development? Brief Funct. Genomic Proteomic. 2004;3:47-59.

30. Duncan T, Valenzuela M. Alzheimer's disease, dementia, and stem cell therapy. Stem Cell Res Ther. 2017;8(1):111. https://doi.org/10.1186/s13287017-0567-5.

31. Ebert AD, Yu J, Rose FF Jr, Mattis VB, Lorson CL, Thomson JA, Svendsen CN. Induced pluripotent stem cells from a spinal muscular atrophy patient. Nature. 2009;457:277-80

32. Edmondson R, Adcock AF, Yang L, Liu G, Diot A, Xirodimas D. Influence of matrices on 3D-cultured prostate cancer cells' drug response and expression of drug-action associated proteins. PLoS One. 2016;11:e0158116.

33. Extance A. Alzheimer's failure raises questions about disease-modifying strategies. Nat Rev Drug Discov. 2010;9(10):749-51. https://doi.org/10.1038/ nrd3288.

34. Fan $X$, Sun $D$, Tang $X$ Cai $Y$, Yin $Z Q$, and $X u H$. Stem cell challenges in the treatment of Alzheimer's disease: a long way from bench to bedside. Med. Res. Rev. 2014; 34, 957-978.

35. Fishell G, Heintz N. The Neuron Identity Problem: Form Meets Function. Neuron. 2013; 80:602-612. PMID: 24183013. https://doi.org/10.1016/j.neuron. 2013.10.035

36. Fong LK, Yang MM, Dos Santos CR, Reyna SM, Langness F, Woodruff G, Roberts $E A$, Young JE, Goldstein LSB. Full-length amyloid precursor protein regulates lipoprotein metabolism and amyloid- $\beta$ clearance in human astrocytes. J Biol Chem. 2018;293(29):11341-57. https://doi.org/10.1074/jbc.RA117.000441.

37. García-León JA, Cabrera-Socorro A, Eggermont K, Swijsen A, Terryn J, Fazal R, Nami F, Ordovás L, et al. Generation of a human induced pluripotent stem cell-based model for tauopathies combining three microtubuleassociated protein tau mutations which displays several phenotypes linked to neurodegeneration. Alzheimers Dement. 2018;18:30161-4. https://doi. org/10.1016/j.jalz.2018.05.007 pii: S1552-5260.

38. Goldstein LS. Axonal transport and neurodegenerative disease: can we see the elephant? Prog Neurobiol. 2012. https://doi.org/10.1016/j.pneurobio. 2012.03.006

39. Goldstein LS, Reyna S, Woodruff G. Probing the secrets of Alzheimer's disease using human-induced pluripotent stem cell technology. Neurotherapeutics. 2015;12(1):121-5. https://doi.org/10.1007/s13311014-0326-6.

40. Grange P, Bohland JW, Okaty BW, Sugino K, Bokil H, Nelson SB, Ng L, Hawrylycz M, Mitra PP. Cell-type-based model explaining coexpression patterns of genes in the brain. Proceedings of the National Academy of Sciences of the United States of America. 2014; 111:5397-5402.

41. Gunawardena S, Goldstein LS. Disruption of axonal transport and neuronal viability by amyloid precursor protein mutations in drosophila. Neuron. 2001;32:389-401.

42. Haenseler W, Sansom SN, Buchrieser J, Newey SE, Moore CS, Nicholls FJ, Chintawar S, et al. A Highly Efficient Human Pluripotent Stem Cell Microglia Model Displays a Neuronal-Co-culture-Specific Expression Profile and Inflammatory Response. Stem Cell Reports. 2017;8(6):1727-42. https://doi. org/10.1016/j.stemcr.2017.05.017.

43. Holtzman DM, Morris JC, Goate AM. Alzheimer's disease: the challenge of the second century. Sci. Transl. Med. 2011;3:77sr71.

44. Hossini AM, Megges M, Prigione A, Lichtner B, Toliat MR, Wruck W, Schröter $F$, et al. Induced pluripotent stem cell-derived neuronal cells from a sporadic Alzheimer's disease donor as a model for investigating ADassociated gene regulatory networks. BMC Genomics. 2015;16:84. https:// doi.org/10.1186/s12864-015-1262-5.

45. Hossini AM, Quast AS, Plötz M, Grauel K, Exner T, Küchler J, Stachelscheid H, et al. PI3K/AKT Signaling Pathway Is Essential for Survival of Induced pluripotent Stem Cells. PLoS One. 2016;11(5):e0154770. https://doi.org/10. 1371/journal.pone.0154770.

46. Imm J, Kerrigan $T L$, Jeffries A, Lunnon K. Using induced pluripotent stem cells to explore genetic and epigenetic variation associated with Alzheimer's disease. Epigenomics. 2017;9(11):1455-68. https://doi.org/10. 2217/epi-2017-0076 Epub 2017 Oct 3. 
47. Inoue $H$, Nagata $N$, Kurokawa $H$, Yamanaka S. iPS cells: a game changer for future medicine. EMBO J. 2014;33(5):409-17.

48. Israel MA, Yuan SH, Bardy C, Reyna SM, Mu Y, Herrera C, Hefferan MP, Van Gorp S, Nazor KL, et al. Probing sporadic and familial Alzheimer's disease using induced pluripotent stem cells. Nature. 2012;482(7384):216-20. https://doi.org/10.1038/nature10821.

49. Izuo N, Murakami K, Sato M, Iwasaki M, Izumi Y, Shimizu T, Akaike A, Irie K, Kume T. Non-toxic conformer of amyloid $\beta$ may suppress amyloid $\beta$ inducedtoxicity in rat primary neurons: implications for a novel therapeutic strategy for Alzheimer's disease. Biochem Biophys Res Commun. 2013; 438(1):1-5. https://doi.org/10.1016/j.bbrc.2013.05.106.

50. Jang J, Yoo JE, Lee JA, Lee DR, Kim JY, Huh YJ, Kim DS, Park CY, Hwang DY, Kim HS, Kang HC, Kim DW. Disease-specific induced pluripotent stem cells: a platform for human disease modeling and drug discovery. Exp Mol Med. 2012;44(3):202-13. https://doi.org/10.3858/emm.2012.44.3.015.

51. Jones VC, Atkinson-Dell R, Verkhratsky A, Mohamet L. Aberrant iPSC-derived human astrocytes in Alzheimer's disease. Cell Death Dis. 2017;8(3):e2696. https://doi.org/10.1038/cddis.2017.89.

52. Karch CM, Hernández D, Wang JC, Marsh J, Hewitt AW, Hsu S, et al. Dominantly Inherited Alzheimer Network (DIAN), Pébay A ${ }^{2,3}$, Goate AM ${ }^{12}$. Human fibroblast and stem cell resource from the Dominantly Inherited Alzheimer Network. Alzheimers Res Ther. 2018;10(1):69.

53. Karran E, Hardy J. A critique of the drug discovery and phase 3 clinical programs targeting the amyloid hypothesis for Alzheimer disease. Ann. Neurol., 76 (2014), pp. 185-205.

54. Koch P, Tamboli IY, Mertens J, Wunderlich P, Ladewig J, Stüber K, Esselmann H, Wiltfang J, Brüstle O, Walter J. Presenilin-1 L166P mutant human pluripotent stem cell-derived neurons exhibit partial loss of $\gamma$-secretase activity in endogenous amyloid- $\beta$ generation. Am J Pathol. 2012;180(6): 2404-16. https://doi.org/10.1016/j.ajpath.2012.02.012.

55. Kondo T, Asai M, Tsukita K, Kutoku Y, Ohsawa Y, Sunada Y, Imamura K, Egawa N, Yahata N, et al. Modeling Alzheimer's disease with iPSCs reveals stress phenotypes associated with intracellular $A \beta$ and differential drug responsiveness. Cell Stem Cell. 2013;12(4):487-96. https://doi.org/10.1016/j. stem.2013.01.009.

56. Lancaster MA, Renner M, Martin C-A, Wenzel D, Bicknell LS, Hurles ME, et al. Cerebral organoids model human brain development and microcephaly. Nature. 2013;501:373-9.

57. Laws KR., Irvine K, Gale TM. Sex differences in cognitive impairment in Alzheimer's disease. World J. Psychiatry. 2016;6(1):54-65. https://doi.org/10. 5498/wjp.v6.i1.54

58. Lazarov O, Demars MP. All in the family: how the APPs regulate neurogenesis. Front Neurosci. 2012;6:81.

59. Lee HK, Morin P, Xia W. Peripheral blood mononuclear cell-converted induced pluripotent stem cells (iPSCs) from an early onset Alzheimer's patient. Stem Cell Res. 2016;16(2):213-5. https://doi.org/10.1016/j.scr.2015.12.050.

60. Lee JK, Jin HK, Park MH, Kim BR, Lee PH, Nakauchi H, Carter JE, He X, Schuchman EH, Bae JS. Acid sphingomyelinase modulates the autophagic process by controlling lysosomal biogenesis in Alzheimer's disease. J Exp Med. 2014;211(8):1551-70. https://doi.org/10.1084/jem.20132451.

61. Lee G, Papapetrou EP, Kim H, Chambers SM, Tomishima MJ, Fasano CA, Ganat YM, Menon J, Shimizu F, Viale A, et al. Modelling pathogenesis and treatment of familial dysautonomia using patient-specific iPSCs. Nature. 2009;461:402-6.

62. Lee VM, Brunden KR, Hutton M, Trojanowski JQ. Developing therapeutic approaches to tau, selected kinases, and related neuronal protein targets. Cold Spring Harb Perspect Med. 2011;1:a006437.

63. Levy S, Sutton G, Ng PC, et al. The diploid genome sequence of an individual human. PLoS Biol. 2007;5:e254.

64. Li T, Pires C, Nielsen T, Waldemar G, Hjermind LE, Nielsen JE, Dinnyes A, Holst B, Hyttel P, Freude KK. Generation of induced pluripotent stem cells (iPSCS) from an Alzheimer's disease patient carrying a M146I mutation in PSEN1. Stem Cell Res. 2016;16(2):334-7. https://doi.org/10.1016/j.scr.2016.01.001.

65. Li T, Pires C, Nielsen TT, Waldemar G, Hjermind LE, Nielsen JE, Dinnyes A, Hyttel P, Freude KK. Generation of induced pluripotent stem cells (iPSCs) from an Alzheimer's disease patient carrying an A79V mutation in PSEN1. Stem Cell Res. 2016;16(2):229-32. https://doi.org/10.1016/j.scr.2016.01.002.

66. Li Y, Muffat J, Omer A, Bosch I, Lancaster MA, Sur M, et al. Induction of expansion and folding in human cerebral organoids. Cell Stem Cell. 2017; 20(3):385-96.e3.

67. Liao MC, Muratore CR, Gierahn TM, Sullivan SE, Srikanth P, De Jager PL, Love JC, Young-Pearse TL. Single-Cell Detection of Secreted A $\beta$ and SAPPa from
Human IPSC-Derived Neurons and Astrocytes. J Neurosci. 2016;36(5):173046. https://doi.org/10.1523/JNEUROSCI.2735-15.2016.

68. Liu Q, Waltz S, Woodruff G, Ouyang J, Israel MA, Herrera C, Sarsoza F, Tanzi $\mathrm{RE}$, Koo EH, et al. Effect of potent $\gamma$-secretase modulator in human neurons derived from multiple presenilin 1-induced pluripotent stem cell mutant carriers. JAMA Neurol. 2014;71(12):1481-9. https://doi.org/10.1001/ jamaneurol.2014.2482.

69. Livesey MR, Magnani D, Hardingham GE, Chandran S, Wyllie DJA. Functional properties of in vitro excitatory cortical neurons derived from human pluripotent stem cells. J Physiol. 2016;594(22):6573-82.

70. Mahairaki V, Ryu J, Peters A, Chang Q, Li T, Park TS, Burridge PW, Talbot CC Jr, Asnaghi L, Martin LJ, Zambidis ET, Koliatsos VE. Induced pluripotent stem cells from familial Alzheimer's diseasepatients differentiate into mature neurons with amyloidogenic properties. Stem Cells Dev. 2014;23(24):29963010. https://doi.org/10.1089/scd.2013.0511.

71. Maloney JA, Bainbridge T, Gustafson A, Zhang S, Kyauk R, Steiner P, van der Brug M, Liu Y, Ernst JA, Watts RJ, Atwal JK. Molecular mechanisms of Alzheimer disease protection by the A673T allele of amyloid precursor protein. J Biol Chem. 2014;289(45):30990-1000. https://doi.org/10.1074/jbc.M114.589069.

72. Marchetto MC, Brennand KJ, Boyer LF, Gage FH. Induced pluripotent stem cells (iPSCs) and neurological disease modeling: progress and promises. Hum Mol Genet. 2011;20:R109-15.

73. Mariani J, Simonini MV, Palejev D, et al. Modeling human cortical development in vitro using induced pluripotent stem cells. Proc Natl Acad Sci U S A. 2012;109(31):12770-5.

74. Mitne-Neto M, Machado-Costa M, Marchetto MC, Bengtson MH, Joazeiro CA, Tsuda H, Bellen HJ, Silva HC, Oliveira AS, Lazar M, et al. Downregulation of VAPB expression in motor neurons derived from induced pluripotent stem cells of ALS8 patients. Hum Mol Genet. 2011;20:3642-52.

75. Mungenast AE, Siegert S, Tsai LH. Modeling Alzheimer's disease with human induced pluripotent stem (iPS) cells. Mol Cell Neurosci. 2016 Jun;73:13-31. https://doi.org/10.1016/j.mcn.2015.11.010 Epub 2015 Dec 4.

76. Muratore CR, Rice HC, Srikanth P, Callahan DG, Shin T, Benjamin LN, Walsh DM, Selkoe DJ, Young-Pearse TL. The familial Alzheimer's disease APPV717I mutation alters APP processing and Tau expression in iPSC-derived neurons. Hum Mol Genet. 2014;23(13):3523-36. https://doi.org/10.1093/hmg/ddu064.

77. Muratore CR, Zhou C, Liao M, Fernandez MA, Taylor WM, Lagomarsino VN, Pearse RV 2nd, et al. Cell-type Dependent Alzheimer's Disease Phenotypes: Probing the Biology of Selective Neuronal Vulnerability. Stem Cell Reports. 2017;9(6):1868-84. https://doi.org/10.1016/j.stemcr.2017.10.015.

78. Nguyen HN, Byers B, Cord B, Shcheglovitov A, Byrne J, Gujar P, Kee K, Schule B, Dolmetsch RE, Langston W, et al. LRRK2 mutant iPSC-derived DA neurons demonstrate increased susceptibility to oxidative stress. Cell Stem Cell. 2011;8:267-80.

79. Nieweg K, Andreyeva A, van Stegen B, Tanriöver G, Gottmann K. Alzheimer's disease-related amyloid- $\beta$ induces synaptotoxicity in human iPS cell-derived neurons. Cell Death Dis. 2015;6:e1709. https://doi.org/10.1038/cddis.2015.72.

80. Ochalek A, Mihalik B, Avci HX, Chandrasekaran A, Téglási A, Bock I, Giudice ML, et al. Neurons derived from sporadic Alzheimer's disease iPSCs reveal elevated TAU hyperphosphorylation, increased amyloid levels, and GSK3B activation. Alzheimers Res Ther. 2017;9(1):90. https://doi.org/10.1186/s13195-017-0317-z.

81. Oka S, Leon J, Sakumi K, Ide T, Kang D, LaFerla FM, Nakabeppu Y. Human mitochondrial transcriptional factor A breaks the mitochondria-mediated vicious cycle in Alzheimer's disease. Sci Rep. 2016;6:37889. https://doi.org/10. 1038/srep37889.

82. Oksanen M, Petersen AJ, Naumenko N, Puttonen K, Lehtonen Š, Gubert Olivé M, Shakirzyanova A, et al. PSEN1 Mutant iPSC-Derived Model Reveals Severe Astrocyte Pathology in Alzheimer's Disease. Stem Cell Reports. 2017; 9(6):1885-97. https://doi.org/10.1016/j.stemcr.2017.10.016.

83. Ooi L, Sidhu K, Poljak A, Sutherland G, O'Connor MD, Sachdev P, Münch G. Induced pluripotent stem cells as tools for disease modelling and drug discovery in Alzheimer's disease. J Neural Transm (Vienna). 2013;120(1):10311. https://doi.org/10.1007/s00702-012-0839-2 Epub 2012 Jun 13.

84. Ortiz-Virumbrales M, Moreno CL, Kruglikov I, Marazuela P, Sproul A, Jacob S, Zimmer M, et al. CRISPR/Cas9-Correctable mutation-related molecular and physiological phenotypes in iPSC-derived Alzheimer's PSEN2 ${ }^{\mathrm{N} 1411}$ neurons. Acta Neuropathol Commun. 2017;5(1):77. https://doi.org/10.1186/s40478-017-0475-z.

85. Ovchinnikov DA, Korn O, Virshup I, Wells CA, Wolvetang EJ. The Impact of APP on Alzheimer-like Pathogenesis and Gene Expression in Down Syndrome iPSC-Derived Neurons. Stem Cell Reports. 2018;11(1):32-42. https://doi.org/10.1016/j.stemcr.2018.05.004. 
86. Paquet D, Kwart D, Chen A, Sproul A, Jacob S, Teo S, Olsen KM, Gregg A, et al. Efficient introduction of specific homozygous and heterozygous mutations using CRISPR/Cas9. Nature. 2016;533(7601):125-9. https://doi.org/ 10.1038/nature17664.

87. Park $\mathrm{H}$, Arora N, Huo H, Maherali N, Ahfeldt T, Shimamura A, Lensch MW, Cowan C, Hochedlinger K, Daley GQ. Disease-specific induced pluripotent stem cells. Cell. 2008;134:877-86.

88. Pires C, Schmid B, Petræus C, Poon A, Nimsanor N, Nielsen TT, Waldemar G, Hjermind $L E$, et al. Generation of a gene-corrected isogenic control cell line from an Alzheimer's disease patient iPSC line carrying a A79V mutation in PSEN1. Stem Cell Res. 2016;17(2):285-8. https:/doi.org/10.1016/j.scr.2016.08.002

89. Poon A, Li T, Pires C, Nielsen TT, Nielsen JE, Holst B, Dinnyes A, Hyttel P, Freude KK. Derivation of induced pluripotent stem cells from a familial Alzheimer's disease patient carrying the L282F mutation in presenilin 1. Stem Cell Res. 2016;17(3):470-3. https://doi.org/10.1016/j.scr.2016.09.016.

90. Poon A, Schmid B, Pires C, Nielsen TT, Hjermind LE, Nielsen JE, Holst B, Hyttel P, Freude KK. Generation of a gene-corrected isogenic control hiPSC line derived from a familial Alzheimer's disease patient carrying a L150P mutation in presenilin 1. Stem Cell Res. 2016;17(3):466-9. https://doi.org/10. 1016/j.scr.2016.09.018.

91. Portelius E, Durieu E, Bodin M, Cam M, Pannee J, Leuxe C, Mabondzo A, Oumata N, et al. Specific Triazine Herbicides Induce Amyloid- $\beta 42$ Production. J Alzheimers Dis. 2016;54(4):1593-605.

92. Prakash A, Medhi B, Chopra K. Granulocyte colony stimulating factor (GCSF) improves memory and neurobehavior in an amyloid- $\beta$ induced experimental model of Alzheimer's disease. Pharmacol Biochem Behav. 2013;110:46-57. https://doi.org/10.1016/j.pbb.2013.05.015

93. Qian X, Nguyen HN, Song MM, Hadiono C, Ogden SC, Hammack C, et al. Brain-region-specific organoids using mini-bioreactors for modeling ZIKV exposure. Cell. 2016;165:1238-54.

94. Robbins JP, Price J. Human induced pluripotent stem cells as a research tool in Alzheimer's disease. Psychol Med. 2017:47(15):2587-92.

95. Rodríguez-Arellano JJ, Parpura V, Zorec R, Verkhratsky A. Astrocytes in physiological aging and Alzheimer's disease. Neuroscience. 2016;323:170-82.

96. Rose SE, Frankowski H, Knupp A, Berry BJ, Martinez R, Dinh SQ, Bruner LT, et al. Leptomeninges-Derived Induced pluripotent Stem Cells and Directly Converted Neurons From Autopsy Cases With Varying Neuropathologic Backgrounds. J Neuropathol Exp Neurol. 2018;77(5):353-60. https://doi.org/ 10.1093/jnen/nly013.

97. Saurat NG, Livesey FJ, Moore S. Cortical Differentiation of Human Pluripotent Cells for In Vitro Modeling of Alzheimer's Disease. Methods Mol Biol. 2016;1303:267-78. https://doi.org/10.1007/978-1-4939-2627-5_16.

98. Schröter F, Sleegers K, Cuyvers E, Bohndorf M, Wruck W, Van Broeckhoven C, Adjaye J. Lymphoblast-derived integration-free iPS cell line from a female 67year-old Alzheimer's disease patient with TREM2 (R47H) missense mutation. Stem Cell Res. 2016;17(3):553-5. https://doi.org/10.1016/j.scr.2016.10.005.

99. Schröter F, Sleegers K, Cuyvers E, Bohndorf M, Wruck W, Van Broeckhoven C, Adjaye J. Lymphoblast-derived integration-free iPS cell line from a 65year-old Alzheimer's disease patient expressing the TREM2 p.R47H variant. Stem Cell Res. 2016;16(1):113-5. https://doi.org/10.1016/j.scr.2015.12.017.

100. Schröter F, Sleegers K, Van Cauwenberghe C, Bohndorf M, Wruck W, Van Broeckhoven C, Adjaye J. Lymphoblast-derived integration-free iPSC lines from a female and male Alzheimer's disease patient expressing different copy numbers of a coding CNV in the Alzheimer risk gene CR1. Stem Cell Res. 2016;17(3):560-3. https://doi.org/10.1016/j.scr.2016.10.003.

101. Seibler P, Graziotto J, Jeong H, Simunovic F, Klein C, Krainc D. Mitochondrial Parkin recruitment is impaired in neurons derived from mutant PINK1 induced pluripotent stem cells. J Neurosci. 2011;31:5970-6.

102. Seo J, Kritskiy O, Watson LA, Barker SJ, Dey D, Raja WK, Lin YT, Ko T, Cho S, Penney J, et al. Inhibition of p25/Cdk5 Attenuates Tauopathy in Mouse and iPSC Models of Frontotemporal Dementia. J Neurosci. 2017;37(41):9917-24. https://doi.org/10.1523/JNEUROSCI.0621-17.2017.

103. Schwarz JM., Sholar PW, Bilbo SD. Sex differences in microglial colonization of the developing rat brain. J. Neurochem. 2012;120(6):948-963.

104. Shi Y, Kirwan P, Smith J, MacLean G, Orkin SH, Livesey FJ. A human stem cell model of early Alzheimer's disease pathology in Down syndrome. Sci Transl Med. 2012;4(124):124ra29. https://doi.org/10.1126/scitranslmed.3003771.

105. Siegert S, Cabuy E, Scherf BG, Kohler H, Panda S, Le YZ, Fehling HJ, Gaidatzis D, Stadler MB, Roska B. Transcriptional code and disease map for adult retinal cell types. Nat Neurosci. 2012; 15:487-95. S1-2. PMID: 22267162. https://doi.org/10.1038/nn.3032.
106. Sjöbeck M, Englund E. Alzheimer's disease and the cerebellum: a morphologic study on neuronal and glial changes. Dement. Geriatr. Cogn. Disord. 2001;12(3):211-218. https://doi.org/10.1159/000051260

107. Sullivan SE, Young-Pearse TL.Induced pluripotent stem cells as a discovery tool for Alzheimer's disease. Brain Res. 2017;1656:98-106. https://doi.org/10. 1016/j.brainres.2015.10.005. Epub 2015 Oct 13.

108. Sullivan SE, Young-Pearse TL. Induced pluripotent stem cells as a discovery tool for Alzheimer $s$ disease. Brain Res. 2015;1656:98-106.

109. Tagami S, Yanagida K, Kodama TS, Takami M, Mizuta N, Oyama H, Nishitomi K, Chiu Y-w, Okamoto T, Ikeuchi T, Sakaguchi G, Kudo T, Matsuura Y, Fukumori A, Takeda M, Ihara Y, Okochi M. Semagacestat Is a PseudoInhibitor of $\gamma$-Secretase. Cell Rep. 2017;21(1):259-73.

110. Tong G, Izquierdo P, Raashid RA. Human Induced Pluripotent Stem Cells and the Modelling of Alzheimer's Disease: The Human Brain Outside the Dish. Open Neurol J. 2017:11:27-38. Published 2017 Sep 30. https://doi.org/ 10.2174/1874205X01711010027

111. Tong M, Dominguez C, Didsbury J, de la Monte SM. Targeting Alzheimer's Disease Neuro-Metabolic Dysfunction with a Small Molecule Nuclear Receptor Agonist (T3D-959) Reverses Disease Pathologies. J Alzheimers Dis Parkinsonism. 2016;6(3):238.

112. Selkoe DJ.Preventing Alzheimer's disease. Science. 2012;337(6101):1488-92.

113. Shirotani K, Matsuo K, Ohtsuki S, Masuda T, Asai M, Kutoku Y, Ohsawa Y, et al. A simplified and sensitive method to identify Alzheimer's diseasebiomarker candidates using patient-derived induced pluripotent stem cells (iPSCs). J Biochem. 2017;162(6):391-4. https://doi.org/10.1093/jb/ mvx058.

114. Siegel G, Gerber $H$, Koch P, Bruestle O, Fraering PC, Rajendran L. The Alzheimer's Disease $\gamma$-Secretase Generates Higher 42:40 Ratios for $\beta$-Amyloid Than for p3 Peptides. Cell Rep. 2017;19(10):1967-76. https://doi.org/10.1016/ j.celrep.2017.05.034

115. Soldner F, Hockemeyer D, Beard C, Gao Q, Bell GW, Cook EG, Hargus G, Blak A, Cooper O, Mitalipova M, et al. Parkinson's disease patient-derived induced pluripotent stem cells free of viral reprogramming factors. Cell. 2009:136:964-77.

116. Sproul AA, Jacob S, Pre D, Kim SH, Nestor MW, Navarro-Sobrino M, SantaMaria I, et al. Characterization and molecular profiling of PSEN1 familial Alzheimer's disease iPSC-derived neural progenitors. PLoS One. 2014;9(1): e84547. https://doi.org/10.1371/journal.pone.0084547.

117. Sproul AA, Vensand LB, Dusenberry CR, Jacob S, Vonsattel JP, Paull DJ, Shelanski ML, Crary JF, Noggle SA. Generation of iPSC lines from archived non-cryoprotected biobanked dura mater. Acta Neuropathol Commun. 2014;2:4. https://doi.org/10.1186/2051-5960-2-4.

118. Stein $J$, De La Torre-Ubieta L, Tian Y, et al. A quantitative framework to evaluate modeling of cortical development by neural stem cells. Neuron. 2014:83(1):69-86.

119. Streit WJ, Braak H, Xue QS, Bechmann I. Dystrophic (senescent) rather than activated microglial cells are associated with tau pathology and likely precede neurodegeneration in Alzheimer's disease. Acta Neuropathol. 2009; 118:475-85. PMID: 19513731. https://doi.org/10.1007/s00401-009-0556-6

120. Takahashi $K$, et al. Induction of pluripotent stem cells from adult human fibroblasts by defined factors. Cell. 2007;131(5):861-72.

121. Takahashi K, Yamanaka S. Induction of pluripotent stem cells from mouse embryonic and adult fibroblast cultures by defined factors. Cell. 2006;126(4): 663-76.

122. Takamatsu K, Ikeda T, Haruta M, Matsumura K, Ogi Y, Nakagata N, Uchino M, et al. Degradation of amyloid beta by human induced pluripotent stem cell-derived macrophages expressing Neprilysin-2. Stem Cell Res. 2014;13(3 Pt A):442-53. https://doi.org/10.1016/j.scr.2014.10.001.

123. Tubsuwan A, Pires C, Rasmussen MA, Schmid B, Nielsen JE, Hjermind LE, Hall $V$, Nielsen $\pi$, et al. Generation of induced pluripotent stem cells (iPSCs) from an Alzheimer's disease patient carrying a L150P mutation in PSEN-1. Stem Cell Res. 2016:16(1):110-2. https://doi.org/10.1016/j.scr.2015.12.015.

124. Usenovic M, Niroomand S, Drolet RE, Yao L, Gaspar RC, Hatcher NG, Schachter J, et al. Internalized Tau Oligomers Cause Neurodegeneration by Inducing Accumulation of Pathogenic Tau in Human Neurons Derived from Induced pluripotent Stem Cells. J Neurosci. 2015;35(42):14234-50. https:// doi.org/10.1523/JNEUROSCI.1523-15.2015.

125. Vazin T, Ball KA, Lu H, Park H, Ataeijannati Y, Head-Gordon T, Poo MM, Schaffer DV. Efficient derivation of cortical glutamatergic neurons from human pluripotent stem cells: a model system to study neurotoxicity in Alzheimer's disease. Neurobiol Dis. 2014;62:62-72. https://doi.org/10.1016/j.nbd.2013.09.005 
126. Wang Z, Zhang P, Wang Y, Shi C, Jing N, Sun H, Yang J, Liu Y, Wen $X$, et al. Establishment of induced pluripotent stem cell line (ZZUi010-A) from an Alzheimer's disease patient carrying an APP gene mutation. Stem Cell Res. 2017;25:213-6. https://doi.org/10.1016/.jscr.2017.10.025.

127. Weick JP. Functional properties of human stem cell-derived neurons in health and disease. Stem Cells Int. 2016;2016:4190438.

128. Woodruff G, Reyna SM, Dunlap M, Van Der Kant R, Callender JA, Young JE, Roberts EA, Goldstein LS. Defective Transcytosis of APP and Lipoproteins in Human iPSC-Derived Neurons with Familial Alzheimer's Disease Mutations. Cell Rep. 2016;17(3):759-73. https://doi.org/10.1016/j.celrep.2016.09.034.

129. Woodruff G, Young JE, Martinez FJ, Buen F, Gore A, Kinaga J, Li Z, Yuan SH Zhang K, Goldstein LS. The presenilin-1 $\triangle \mathrm{E} 9$ mutation results in reduced $\gamma$ secretase activity, but not total loss of PS1 function, in isogenic human stem cells. Cell Rep. 2013;5(4):974-85. https://doi.org/10.1016/j.celrep.2013. 10.018 .

130. Yagi T, Ito D, Okada Y, Akamatsu W, Nihei Y, Okano H, Suzuki N. Modeling familial Alzheimer's disease with induced pluripotent stem cells. Rinsho Shinkeigaku. 2012;52(11):1134-6.

131. Yagi T, Ito D, Okada Y, Akamatsu W, Nihei Y, Yoshizaki T, Yamanaka S, Okano $H$, Suzuki N. Modeling familial Alzheimer's disease with induced pluripotent stem cells. Hum Mol Genet. 2011;20(23):4530-9. https://doi.org/10.1093/ $\mathrm{hmg} / \mathrm{ddr} 394$.

132. Yagi T, Kosakai A, Ito D, Okada Y, Akamatsu W, Nihei Y, Nabetani A, Ishikawa F, Arai Y, Hirose N, Okano H, Suzuki N. Establishment of induced pluripotent stem cells from centenarians for neurodegenerative disease research. PLoS One. 2012:7(7):e41572. https://doi.org/10.1371/journal pone.0041572.

133. Yahata N, Asai M, Kitaoka S, Takahashi K, Asaka I, Hioki H, Kaneko T, Maruyama K, Saido TC, et al. Anti-A $\beta$ drug screening platform using human iPS cell-derived neurons for the treatment of Alzheimer's disease. PLoS One. 2011;6(9):e25788. https://doi.org/10.1371/journal.pone.0025788.

134. Yang Y, Zhang X, Yi L, et al. Naiive Induced Pluripotent Stem Cells Generated From $\beta$-Thalassemia Fibroblasts Allow Efficient Gene Correction With CRISPR/Cas9. Stem Cells TransI Med. 2016; 5(1): 8-19.

135. Yang J, Zhao H, Ma Y, Shi G, Song J, Tang Y, Li S, Li T, Liu N, Tang F, Gu J, et al. Early pathogenic event of Alzheimer's disease documented in iPSCS from patients with PSEN1 mutations. Oncotarget. 2017;8(5):7900-13. https:// doi.org/10.18632/oncotarget.13776.

136. Young JE, Boulanger-Weill J, Williams DA, Woodruff G, Buen F, Revilla AC, et al. Elucidating molecular phenotypes caused by the SORL1 Alzheimer's disease genetic risk factor using human induced pluripotent stem cells. Cell Stem Cell. 2015;16(4):373-85. https://doi.org/10.1016/j.stem.2015.02.004.

137. Young JE, Goldstein LS. Alzheimer's disease in a dish: promises and challenges of human stem cell models. Hum Mol Genet. 2012;21 (R1):R82-9. Epub 2012 Aug 2

138. Zagni E, Simoni L, Colombo D. Sex and Gender Differences in Central Nervous System-Related Disorders. Neurosci J. 2016;2016:2827090. https:// doi.org/10.1155/2016/2827090 Epub 2016 May 30.

139. Zhang D, Pekkanen-Mattila M, Shahsavani M, Falk A, Teixeira Al, Herland A. A 3D Alzheimer's disease culture model and the induction of P21-activated kinase mediated sensing in IPSC derived neurons. Biomaterials. 2014;35(5): 1420-8. https://doi.org/10.1016/j.biomaterials.2013.11.028.

140. Zhang S, Lv Z, Zhang S, Liu L, Li Q, Gong W, Sha H, Wu H. Characterization of human induced pluripotent stem cell (iPSC) line from a 72year old male patient with later onset Alzheimer's disease. Stem Cell Res. 2017;19:34-6. https://doi.org/10.1016/j.scr.2016.12.024.

141. Zhang R, Zhang LH, Xie X. iPSCs and small molecules: a reciprocal effort towards better approaches for drug discovery. Acta Pharmacol Sin. 2013; 34(6):765-76.

142. Zollo A, Allen Z, Rasmussen HF, lannuzzi F, Shi Y, Larsen A, Maier Tf, Matrone C. Sortilin-Related Receptor Expression in Human Neural Stem CellsDerived from Alzheimer's Disease Patients Carrying the APOE Epsilon 4 Allele. Neural Plast. 2017;2017:1892612. https://doi.org/10.1155/2017/ 1892612.

Ready to submit your research? Choose BMC and benefit from:

- fast, convenient online submission

- thorough peer review by experienced researchers in your field

- rapid publication on acceptance

- support for research data, including large and complex data types

- gold Open Access which fosters wider collaboration and increased citations

- maximum visibility for your research: over $100 \mathrm{M}$ website views per year

At $\mathrm{BMC}$, research is always in progress.

Learn more biomedcentral.com/submissions 